
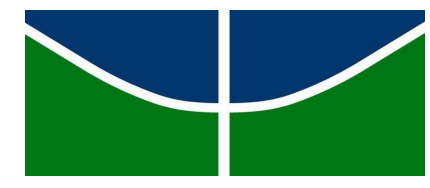

\author{
UNIVERSIDADE DE BRASÍLIA \\ INSTITUTO DE CIÊNCIAS HUMANAS \\ DEPARTAMENTO DE SERVIÇO SOCIAL \\ PROGRAMA DE PÓS-GRADUAÇÃO EM POLÍTICA SOCIAL
}

CAROLINE SOUZA NEVES

PELAS MÃOS DO SOCIOEDUCATIVO:

PRÁTICAS DISCIPLINARES NA MEDIDA SOCIOEDUCATIVA DE INTERNAÇÃO 


\section{Caroline Souza Neves}

\section{Pelas mãos do socioeducativo:}

\section{práticas disciplinares na medida socioeducativa de internação}

Dissertação apresentada ao Programa de Pós-Graduação em Política Social da Universidade de Brasília, como requisito parcial para obtenção do grau de Mestra em Política Social.

Orientadora: Profa. Dra. Debora Diniz.

Brasília 


\section{FICHA CATOLOGRÁFICA}

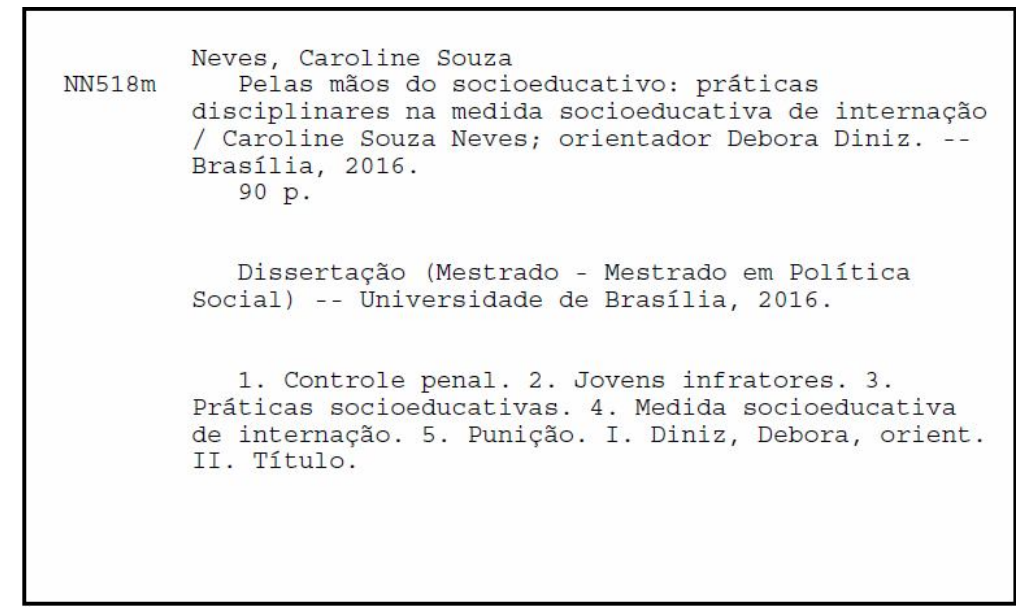




\title{
PELAS MÃOS DO SOCIOEDUCATIVO: \\ PRÁTICAS DISCIPLINARES NA MEDIDA SOCIOEDUCATIVA DE INTERNAÇÃO
}

\author{
Caroline Souza Neves
}

Dissertação submetida ao Programa de Pós-Graduação em Política Social da Universidade de Brasília, como parte dos requisitos necessários para a obtenção do grau de Mestra em Política Social.

Área de Concentração: Estado, Políticas Sociais e Cidadania.

Dissertação apresentada ao Programa de Pós-Graduação em Política Social da Universidade de Brasília, como requisito parcial para obtenção do grau de Mestra em Política Social.

\section{APROVADA POR:}

Profa. Dra. Debora Diniz. (Departamento de Direito - UnB)

(Orientadora)

Prof. Dr. Newton Narciso Gomes Junior. (Departamento de Serviço Social - UnB)

(Membro interno vinculado ao Programa)

Profa. Dra. Lívia Barbosa Pereira. (Departamento de Serviço Social - UnB)

(Membro interno vinculado ao Programa)

Profa. Dra. Tatiana Lionço. (Departamento de Psicologia - UnB)

(Suplente - Membro interno não vinculado ao Programa)

Brasília, 1 de março de 2016. 


\section{AGRADECIMENTOS}

À professora Debora Diniz, pela orientação e por me desafiar a sempre fazer o melhor.

Aos professores Beatriz Vargas e Newton Gomes Junior, que estiveram presentes na banca de qualificação do projeto desta dissertação e trouxeram importantes considerações.

Às professoras Lívia Barbosa e Tatiana Lionço e, novamente, ao professor Newton Gomes, por aceitarem o convite para a banca de defesa desta dissertação.

A todas as pessoas que acompanharam meu processo de escrita e me ajudaram com a sua leitura e comentários, em especial, Natália Vilarins, Cecília Froemming, Luna Borges, Jamila Abdelaziz, Lucas Neves, Alexandre Paixão e Douglas Gomes.

Aos servidores do sistema socioeducativo que contribuíram para a execução do trabalho de campo, concedendo autorização e me recebendo em seu ambiente de trabalho.

Aos servidores do sistema socioeducativo, amigos que fazem o seu melhor e continuam se incomodando.

À minha turma de mestrado, em especial, Ana Paula, Anderson, Hannah e Júlio, pelas trocas de conhecimento, mas principalmente pelos risos nos momentos difíceis. 
Mas presos são quase todos pretos Ou quase pretos Ou quase brancos quase pretos de tão pobres E pobres são como podres E todos sabem como se tratam os pretos Caetano Veloso e Gilberto Gil 


\section{RESUMO}

Esta dissertação teve como objetivo analisar a duplicidade do controle penal sobre jovens infratores em cumprimento de medida socioeducativa de internação no Distrito Federal durante o ano de 2014, a partir do exame das práticas socioeducativas e da atuação dos sistemas de justiça. Nesta pesquisa, jovens infratores são aqueles que estão internados pela prática de ato infracional e que possuem entre 18 e 20 anos de idade. Deste universo, foram analisados os casos dos jovens infratores que apresentaram envolvimento em ocorrências disciplinares ao longo de 2014. O universo teve como base o total de jovens infratores que se encontravam em cumprimento de medida socioeducativa no dia 2 de janeiro de 2015. O trabalho de campo foi realizado nas unidades de internação do Recanto das Emas (Unire), de Saída Sistemática (Uniss) e de Brazlândia (Uibra), localizadas no Distrito Federal, com aplicação de pesquisa documental e observação qualitativa, além do uso da memória do visto como profissional. A fonte principal de pesquisa foram os dossiês dos jovens internados e os registros do cotidiano institucional. A análise dos dados utilizou métodos mistos que envolveram processos de codificação e desenvolvimento de categorias, próprios da pesquisa qualitativa. Verifica-se, nas práticas socioeducativas, uma lógica que visa à educação pela punição e disciplina. De forma particular, em relação aos jovens internados, a maioridade dentro de uma unidade socioeducativa pode tornar-se um limbo para o sistema prisional. Aqueles que cometem ocorrências disciplinares para além dos procedimentos internos de punição têm o sistema prisional acionado por meio de práticas socioeducativas. $\mathrm{O}$ presente estudo ainda se propôs a problematizar a perversidade do procedimento de encaminhamento para delegacia para registro policial e de demais práticas socioeducativas que, em vez de ressocializar, conforme preconizam, disciplinam, punem e normalizam. Das ocorrências disciplinares que ocorreram no ano de 2014, 32\% terminaram em delegacias para registro policial. Na maioria dos casos, trata-se de dano ao patrimônio, de brigas entre jovens ou da posse de algum tipo de substância entorpecente. Deste percentual, 26 (20\%) jovens foram desligados do sistema socioeducativo em virtude da apreensão no sistema prisional em 2014 após o cometimento de uma ocorrência disciplinar dentro de uma unidade de internação. Na maioria das ocorrências, por terem danificado pias, chuveiros, vasos sanitários e colchões. Dessa forma, constata-se que os sistemas socioeducativo e prisional atuam em uma relação de continuidade. O Estado, na figura do sistema de justiça, exerce seu poder de punir de forma contínua, e mesmo simultânea, por meio do sistema socioeducativo e do sistema de justiça criminal sobre os jovens em cumprimento de medida socioeducativa de internação. Neste sentido, a finalidade das medidas socioeducativas como mecanismos de reinserção social em oposição ao sistema prisional não está sendo cumprida. A própria medida socioeducativa de internação não consegue evitar novas internações, incluindo a prisão.

Palavras-chave: Controle penal. Jovens infratores. Práticas socioeducativas. Medida socioeducativa de internação. Punição. 


\begin{abstract}
This dissertation aimed to analyze the duplicity of criminal control over young offenders in fulfillment of socio-educational measure of internment in the Brazilian Federal District during the year 2014 from the examination of the socio-educational practices and the performance of the justice systems. In this research, young offenders are those who are admitted to the practice of an infraction and have between 18 and 20 years old. Of this universe, the cases of young offenders who had involvement in disciplinary incidents during the year 2014 were analyzed. The universe was based on the total of young offenders who were in fulfillment of socio-educative action on January 2, 2015. The fieldwork was conducted in youth detention center of Recanto das Emas (Unire) Systematic output (Uniss) and Brazlândia (Uibra) located in the Federal District with documentary research application and qualitative observation, besides the use of visa memory as a professional. The main source of research was the files of detained youths and records the institutional routine. Data analysis used mixed methods involving coding and development of own categories of qualitative research. Checks whether, in the socioeducative practices, a logic that aims at education for punishment and discipline. In particular, in relation to detained youths, the criminal responsibility within a youth detention center can become a limbo for the prison system. Those who commit disciplinary occurrences beyond internal procedures punishment has the prison system operated by means of socio-educative practices. This study also aimed to discuss the perversity of the procedure to refer to the police station to police record and other socioeducative practices, rather than re-socialize as recommended discipline, punish and normalize. Disciplinary incidents that occurred in 2014, 32\% ended in police stations for police record. In most cases, if dealt with property damage, fights between young or possession of some kind of narcotic substance. This percentage, $26(20 \%)$ young people were disconnected from the socio-educative system as a result of the seizure in the prison system in 2014 after the commission of a disciplinary occurrence within an youth detention center. In most instances, for having damaged sinks, showers, toilets and mattresses. Thus, notes that the systems socio-educative and prison work in a relationship of continuity. The state, in the figure of the justice system, exerts its power to punish continuously and even simultaneously through the socio-educative system and the criminal justice system on youth in fulfilling of socio-educative action. In this sense, the purpose of socio-educative action as mechanisms of social reintegration as opposed to the prison system is not being fulfilled. The own socio-educational measure of internment cannot avoid new admissions, including prison.
\end{abstract}

Key-words: Criminal control. Young offenders. Social and educational practices. Socioeducational measure of internment. Punishment. 


\section{SUMÁRIO}

INTRODUÇÃO

DESENVOLVIMENTO DA PESQUISA …………………................................ 19

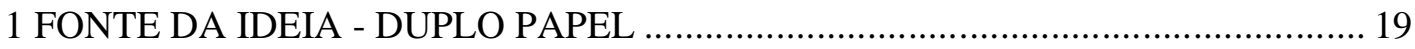

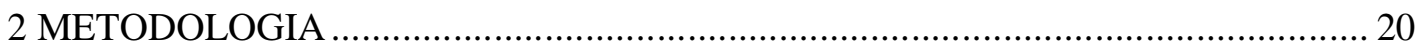

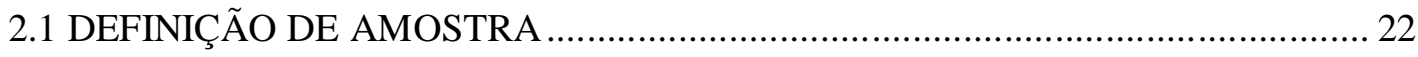

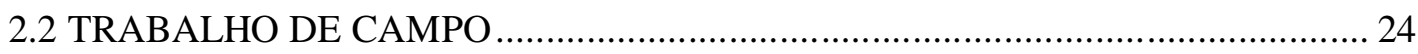

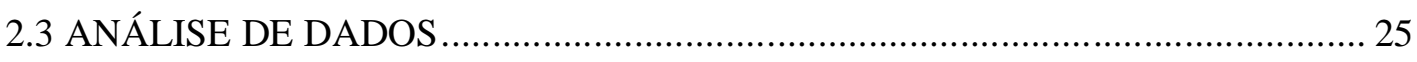

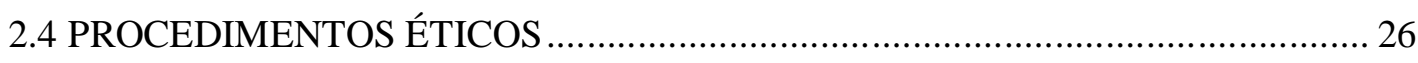

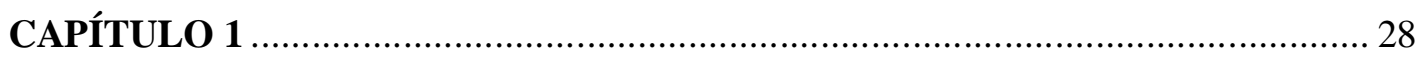

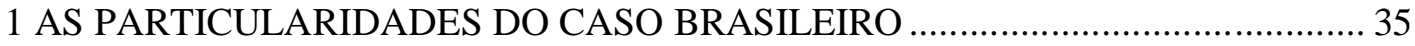

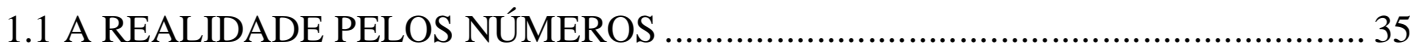

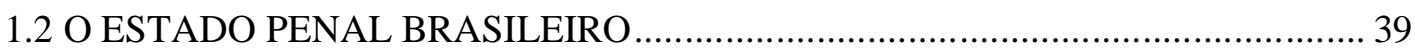

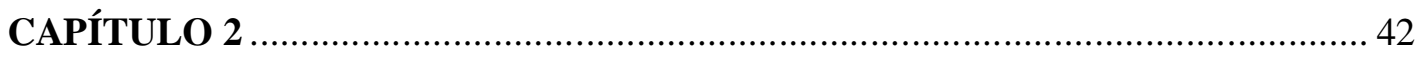

1 A MEDIDA SOCIOEDUCATIVA DE INTERNAÇÃO ………………................. 42

1.1 A DUPLA NATUREZA DA MEDIDA SOCIOEDUCATIVA DE INTERNAÇÃO: UM MISTO "DO CLAUSTRO, DA PRISÃO, DO COLÉGIO, DO REGIMENTO”........................ 44

2 UMA NOVA FORMA DE PUNIR: A TRANSFORMAÇÃO DO INDIVÍDUO OU A RESSOCIALIZAÇÃO DO ADOLESCENTE INFRATOR......................................... 47

2.1 ENTRE SISTEMAS: O SOCIOEDUCATIVO E O PRISIONAL …………………... 48

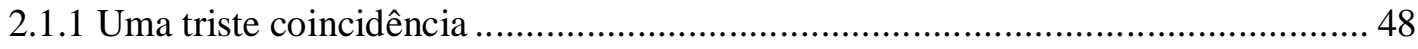

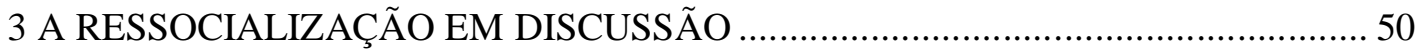

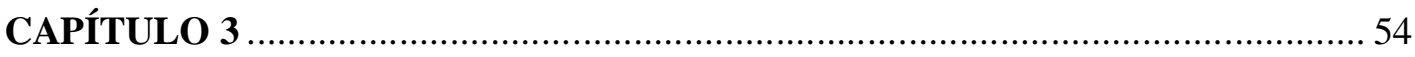

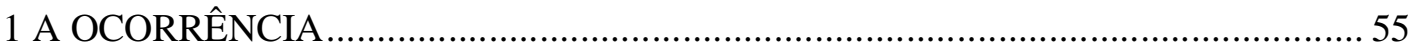

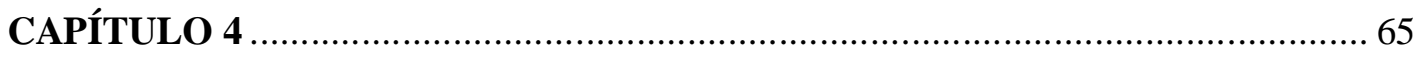

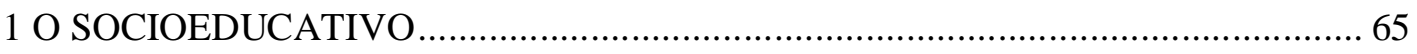

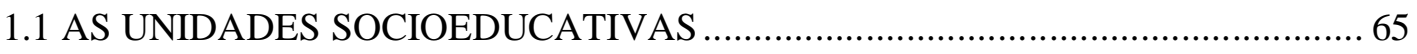

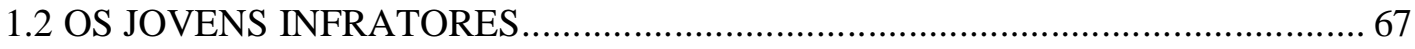

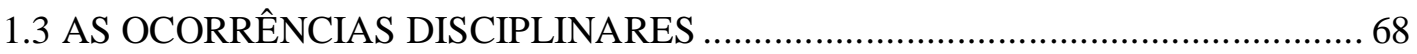

1.3.1 Unidades e ocorrências disciplinares .................................................................. 70

1.4 O PROCEDIMENTO SOCIOEDUCATIVO DE ENCAMINHAMENTO PARA A

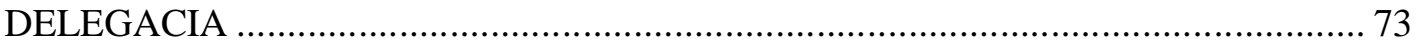

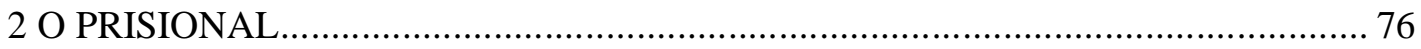


2.1 DO ENCAMINHAMENTO PARA A APREENSÃO

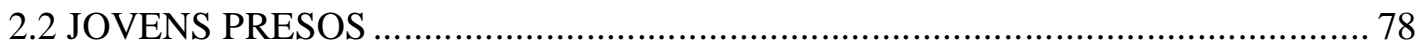

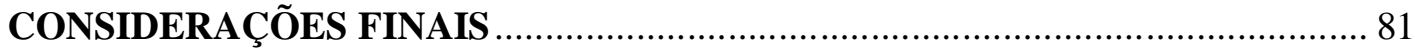

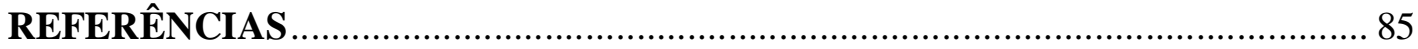




\section{LISTA DE TABELAS}

Tabela 1 Distribuição de jovens envolvidos em ocorrências em 2014 em relação ao total de jovens em cada unidade

Tabela 2 Proporção de jovens internados e jovens envolvidos em ocorrências em 2014 em relação ao efetivo total

Tabela 3 Número de ocorrências disciplinares na Unire -2010 a 2014

Tabela 4 Tipo de ocorrência disciplinar que gerou procedimento de encaminhamento para delegacias

Tabela 5 Desligamentos para o sistema prisional na Unire - 2010 a 2014 


\section{LISTA DE GRÁFICOS}

Gráfico 1 Distribuição do total de jovens internados e a capacidade de lotação

Gráfico 2 Jovens envolvidos em ocorrências disciplinares em 2014 por unidade

Gráfico 3 Ocorrências disciplinares em 2014 por unidade 


\section{NOTA DE ABERTURA}

No Estatuto da Criança e do Adolescente (ECA) e no Sistema Nacional de Atendimento Socioeducativo (Sinase), os adolescentes e jovens envolvidos com a prática de algum tipo de ato infracional são chamados de "adolescentes em conflito com a lei" ou "adolescentes e jovens autores de ato infracional". Nas notícias, estes mesmos adolescentes e jovens são chamados de "menores", "bandidos" e/ou "delinquentes". Ainda, podem ser considerados como "pebas" e "marginais" que saem das periferias da cidade e incomodam nos centros urbanos.

Nesta dissertação, eles são chamados de "adolescentes e jovens infratores". A escolha pela adoção deste termo foi por compreender que a autoria do ato não é passageira. Depois da prática do ato infracional, os adolescentes e jovens deixam de ser simplesmente pessoas em condição peculiar de desenvolvimento, ficando esta noção em segundo plano. A infração é o que os marca, que os define perante a sociedade.

Entendo a importância da adoção pelos marcos regulatórios do sistema socioeducativo dos termos que indiquem a transitoriedade do envolvimento infracional na vida destes adolescentes e jovens, principalmente, para contrapor os termos adotados pela grande mídia e por setores conservadores e reacionários da sociedade. No entanto, adotar "em conflito com a lei" ou "autor de ato infracional" na discussão proposta por esta dissertação de mestrado seria amenizar o tratamento e a condição destes adolescentes e

jovens submetidos ao controle penal do sistema de justiça. 


\section{INTRODUÇÃO}

O Brasil ocupa a quarta posição entre os países que possuem a maior quantidade de pessoas presas no mundo, atrás dos Estados Unidos, China e Rússia. Se forem consideradas as prisões domiciliares, o Brasil ultrapassa a Rússia e assume o terceiro lugar, com mais de meio milhão de pessoas presas. De acordo com o último levantamento do Conselho Nacional de Justiça (CNJ), divulgado no mês de junho de 2014, a nova população carcerária brasileira é de 711.463 presos (BRASIL, 2014a). Neste efetivo, estão contabilizados os 147.937 indivíduos em prisão domiciliar, visto que esta pode ser concedida a presos de qualquer um dos regimes de prisão - fechado, semiaberto e aberto.

Um relatório produzido pelo Grupo de Trabalho sobre Detenção Arbitrária (GTDA), da Organização das Nações Unidas (ONU), que visitou o Brasil em março de 2013, atestou a relação entre o uso excessivo da prisão e a superpopulação carcerária do país. O grupo comprovou que existe uma baixa aplicação, pelo Poder Judiciário, de medidas cautelares substitutivas à prisão, previstas na Lei n. 12.403, de julho de 2011. Nos casos em que medidas como fianças são aplicáveis, detentos não possuem condições financeiras para pagar a quantia estipulada (BRASIL, 2014b). Segundo dados de 2014 divulgados pelo Departamento Penitenciário Nacional (Depen), do Ministério da Justiça, quase metade da população carcerária identificada (43\%) são de condenados e acusados por crimes contra o patrimônio, como furto, roubo, extorsão, receptação e estelionato. Outros $24 \%$ estão presos por tráfico de drogas e $15 \%$ encontram-se presos pelos chamados crimes contra a pessoa, como homicídio, sequestro e cárcere privado (BRASIL, 2014a).

O contexto socioeducativo, isto é, a realidade de adolescentes e jovens infratores internados se assemelha a da justiça criminal do país. São atos contra o patrimônio que mais internam adolescentes e jovens brasileiros, ou seja, que mais encarceram no Brasil sua população masculina, jovem, pobre e negra/parda. Os adolescentes e jovens infratores são responsáveis por $0,9 \%$ do total de crimes praticados no país, conforme pesquisa divulgada pela Secretaria Nacional de Segurança Pública (Senasp), do Ministério da Justiça (COSTA, 2014). De acordo com o Plano Nacional de Atendimento Socioeducativo, o roubo ocupa o primeiro lugar, seguido por tráfico de drogas, na lista dos atos infracionais mais cometidos por adolescentes e jovens infratores que se encontram em privação de liberdade (BRASIL, 2013a). Segundo o último Levantamento 
Anual dos/as Adolescentes em Cumprimento de Medida Socioeducativa, divulgado em 2014 e com dados consolidados de 2013, existem 108.554 adolescentes no Brasil em cumprimento de medidas socioeducativas, sendo 23.066 em regime de restrição e privação de liberdade - internação, internação provisória e semiliberdade - e 88.022 adolescentes em meio aberto - prestação de serviços à comunidade ou liberdade assistida (BRASIL, 2014b).

No Levantamento Anual, apenas o perfil por sexo e idade é apontado. Neste perfil levantado, $5 \%$ do sistema socioeducativo é constituído por meninas e $95 \%$ por meninos, em sua maioria entre 16 e 17 anos de idade (BRASIL, 2014b). A respeito do perfil apresentado pelos adolescentes e jovens em internação estrita aqui no Distrito Federal, a maioria é do sexo masculino (97,5\%), assim como o quadro nacional; 50,2\% têm entre 18 e 21 anos de idade; e, em relação à moradia dos internos, a Região Administrativa (RA) de Ceilândia, com 19,8\%, apareceu em primeiro lugar, seguida de Samambaia, com 12,2\%, e Planaltina, com 11,4\% (GDF, 2013a). Todas essas três Regiões Administrativas do Distrito Federal estão situadas à margem do Plano Piloto e possuem altos índices de violência e pobreza. Com base na autodeclaração dos adolescentes e jovens, os percentuais referentes à raça/cor foram de $48,8 \%$ de parda, seguida por $22,3 \%$ de cor negra $^{1}$ (GDF, 2013a).

São previstas, conforme o Estatuto da Criança e do Adolescente (ECA), em seu artigo n. 112, seis medidas socioeducativas para adolescentes que cometeram algum tipo de ato infracional (crime ou contravenção penal): 1. advertência; 2. obrigação de reparar o dano; 3. prestação de serviços à comunidade; 4. liberdade assistida; 5. inserção em regime de semiliberdade; e 6. internação em estabelecimento educacional. As medidas estão ordenadas pelo grau de severidade, isto é, da mais branda para a mais dura (BRASIL, 1990). A medida socioeducativa de internação constitui-se em medida privativa de liberdade, sujeita aos princípios de brevidade, excepcionalidade e respeito à

\footnotetext{
${ }^{1}$ Esses percentuais apresentados no PPP da Medida Socioeducativa de Internação foram fundamentados nas sinopses estatísticas de 2011 e 2012 . A sinopse é uma espécie de questionário institucional que deve ser respondido mensalmente por diversas equipes de servidores das unidades de medidas socioeducativas. Diante disso, esses percentuais, apesar de traçarem um quadro geral da medida socioeducativa de internação no Distrito Federal, ao não distinguir a maioria de seus dados entre os sexos, falam muito mais dos adolescentes e jovens em cumprimento de medida socioeducativa de internação. A realidade das adolescentes e das jovens infratoras em cumprimento de medida socioeducativa dissolve-se em meio aos números gerais.
} 
condição peculiar de pessoa em desenvolvimento (BRASIL, 1990). Deve ser aplicada somente quando imprescindíveis para se atingir a finalidade pretendida (GDF, 2013a).

A Lei n. 12.594/2012, que institui o Sistema Nacional de Atendimento Socioeducativo (Sinase) e regulamenta a execução das medidas socioeducativas junto ao Estatuto da Criança e do Adolescente (ECA), estabelece o recorte por faixa etária da política da socioeducação. O grupo usuário dessa política é constituído por adolescentes que cometeram algum tipo de ato infracional entre os 12 e 18 anos de idade, sendo o cumprimento de medida socioeducativa passível até 21 anos de idade. De acordo com o ECA, adolescente é a pessoa entre 12 e 18 anos de idade. Pelo Estatuto da Juventude, jovens são aqueles que possuem entre 15 e 29 anos de idade (BRASIL, 2013b). Dessa forma, será utilizado, neste estudo, o termo jovem para indicar as pessoas entre 18 e 20 anos de idade que se encontram em cumprimento de medida socioeducativa. A permanência seria até quando fosse alcançado o objetivo de ressocialização, em termos subjetivos, em termos objetivos até alcançado o desempenho adequado avaliado pela justiça ou até o prazo máximo de três anos ou, ainda, de forma compulsória aos 21 anos de idade (BRASIL, 1990).

A política da socioeducação vem com o propósito de superar fatores de desigualdade, exclusão e violência, de modo a permitir que os adolescentes e jovens infratores "reconstruam seu projeto de vida e se reintegrem socialmente" (BRASIL, 2013a, p. 18). Deste modo, os atos infracionais devem ser compreendidos como fruto de circunstâncias e de problemas que devem ser superados para inserir socialmente e propiciar oportunidades para adolescentes e jovens infratores (BRASIL, 2013a). As práticas socioeducativas e o caráter da ressocialização devem prevalecer nas medidas. Dessa forma, analisar as práticas socioeducativas possibilita refletir sobre como as unidades de internação do sistema socioeducativo, por meio de suas regras, normas e procedimentos, em vez de ressocializar, conforme preconizam seus marcos regulatórios, podem reproduzir técnicas penitenciárias, em que o foco está mais no controle do crime do que no bem-estar do sujeito.

Para cada unidade socioeducativa é obrigatória a elaboração de um regimento interno que regule o funcionamento da unidade, por meio da descrição das atribuições e responsabilidades de cada profissional, desde o dirigente até os educadores, e das condições do exercício da disciplina e da concessão de benefícios ordinários e 
extraordinários (BRASIL, 2012). Para o alcance destas condições, prevê ainda a elaboração de um regime disciplinar para controlar o comportamento dos adolescentes e jovens ali internados, por meio do estabelecimento de punições para determinadas atitudes consideradas proibidas. Estas atitudes classificadas como proibidas passam a se chamar ocorrências disciplinares dentro do contexto socioeducativo.

Neste regime disciplinar, devem constar: a) as tipificações de cada ocorrência como leve, média ou grave e sua respectiva sanção; b) a previsão da instauração formal de um processo disciplinar com garantia de ampla defesa e do contraditório para aplicação de sanção; c) a obrigatoriedade de audiência do interno durante o processo disciplinar; d) a determinação da duração de cada sanção; e) a enumeração das causas ou circunstâncias que eximam, atenuem ou agravem uma sanção e os requisitos necessários para uma possível extinção de sanção; f) a exposição nítida das garantias de defesa; g) a possibilidade de recorrer da decisão; e h) a exigência de uma comissão composta por, no mínimo, três integrantes, sendo que um deve ser obrigatoriamente do corpo técnico (BRASIL, 2012).

Para além deste procedimento interno de apuração e definição de sanção são previstos outros procedimentos dentro das unidades socioeducativas. Como o regime disciplinar independe da responsabilidade civil ou penal decorrente da ocorrência disciplinar cometida, é admissível que o adolescente ou jovem infrator seja encaminhado para delegacias para registro de boletim policial. Esse procedimento, como assim é chamado pela equipe de servidores, pode acarretar, no caso dos jovens, seu ingresso no sistema prisional pela mão do sistema socioeducativo. Uma ocorrência disciplinar no sistema socioeducativo pode se tornar um crime ou uma contravenção penal na delegacia. Assim, o jovem infrator é preso em flagrante, sendo encaminhado de imediato para o sistema prisional, com a possibilidade de abertura de um processo criminal durante o cumprimento de uma medida socioeducativa.

Existe um universo de jovens infratores que, ainda vinculados ao sistema socioeducativo, são encaminhados ao sistema prisional por cometerem ocorrências disciplinares, nos parâmetros socioeducativos, ou crimes e/ou contravenções penais, na linguagem penal, dentro das unidades de internação. Esses jovens ficam presos no sistema prisional por alguns dias, ou mesmo meses, e retornam às unidades de internação para dar continuidade à medida socioeducativa aplicada. Além do fato de permanecer 
apreendido no sistema prisional, a instauração de um processo criminal pode implicar penas a serem cumpridas após o término da medida socioeducativa.

Diante desse quadro, o objetivo desta dissertação foi analisar a duplicidade do controle penal sobre os jovens em cumprimento de medida socioeducativa de internação no Distrito Federal durante o ano de 2014. O presente estudo buscou conhecer quantos e quem são esses jovens infratores que, por meio de práticas socioeducativas e da atuação do sistema de justiça, ficam, ao mesmo tempo, sob o controle do sistema socioeducativo e do sistema prisional. Para isso, foi realizada uma pesquisa qualitativa que envolveu trabalho de campo nas unidades socioeducativas de internação do Distrito Federal que possuem formalmente em seu efetivo jovens em cumprimento de medida socioeducativa de internação: Unidade de Internação do Recanto das Emas (Unire), Unidade de Internação de Saída Sistemática (Uniss) e Unidade de Internação de Brazlândia (Uibra). As informações e os dados obtidos foram posteriormente organizados e analisados, procurando-se apreender os fenômenos não como fatos isolados, mas sim como parte de uma totalidade.

Esta dissertação está dividida em quatro capítulos. Os dois primeiros trazem os referenciais teóricos utilizados para relacionar a internação de jovens em unidades socioeducativas e o duplo controle penal ao qual estão submetidos com o atual avanço do punitivismo do Estado e o significado do encarceramento. O primeiro capítulo traz a discussão a respeito da expansão penal do Estado nos Estados Unidos e da difusão de um novo senso comum penal que descontextualiza a pobreza e o crime de questões sociais, culturais, políticas e econômicas e dita as atuais respostas sociais dadas no campo da política criminal. Observa-se, ainda, uma relação entre as políticas criminais e sociais que impõem os mais diversos controles sobre a população pobre. Pelo exemplo do que está ocorrendo na realidade estadunidense, procura-se problematizar o atual quadro brasileiro.

No segundo capítulo, analisa-se a necessidade de conciliação da dupla natureza da medida socioeducativa de internação a partir da compreensão do que vem sendo realizado dentro das unidades socioeducativas. Por meio da discussão de Michael Foucault sobre o poder de normalização e os mecanismos de vigilância e punição que o envolvem, 
questiona-se o objetivo de ressocializar adolescentes e jovens infratores em cumprimento de medidas socioeducativas. Ainda a partir de Foucault, reflete-se sobre a origem da relação entre os atuais sistemas socioeducativo e prisional. Por fim, a possível alteração do significado do encarceramento de pessoas na atualidade é motivo de discussão.

As práticas socioeducativas adotadas quando do cometimento de ocorrências disciplinares, desde procedimentos e registros a atuações profissionais, são o tema do terceiro capítulo. Por meio do detalhamento de cada momento que envolve a prática de uma ocorrência disciplinar até a definição de sua punição, mostra se as muitas semelhanças encontradas entre práticas socioeducativas e práticas disciplinares e entre o sistema socioeducativo e o sistema prisional.

Por fim, no quarto capítulo, são apresentados os principais dados de pesquisa que fundamentam as conclusões desta dissertação. Nesse capítulo, analisam-se os tipos de ocorrências disciplinares que mais encaminharam jovens em cumprimento de medida socioeducativa de internação a delegacias e prisões em 2014. Por meio da exposição da trajetória de 13 jovens no sistema socioeducativo, intenta-se oferecer uma apreensão crítica de como o sistema de justiça vem atuando no controle de suas vidas desde muito cedo. 


\section{DESENVOLVIMENTO DA PESQUISA}

\section{FONTE DA IDEIA - DUPLO PAPEL}

Desde o mês de outubro de 2010, a função de especialista socioeducativo é exercida pela pesquisadora do presente estudo. Enquanto assistente social parte do corpo técnico da Unidade de Internação do Recanto das Emas (Unire), seu trabalho é realizado diretamente no atendimento de adolescentes e jovens em cumprimento de medida socioeducativa de internação. Sua rotina profissional é composta por atendimentos técnicos e familiares, elaboração de relatórios, estudos de caso, contatos e visitas familiares, participação em conselhos disciplinares, reuniões, audiências e demais atividades que compõem o cotidiano de uma unidade socioeducativa.

Ao longo destes cinco anos, exerceu suas atividades nas equipes técnicas de quatro módulos com características distintas, módulos 09, 08, 03 e 04, respectivamente. No módulo 09, o atendimento técnico era destinado aos internos avaliados com o comportamento excelente. Este módulo funcionava em uma pequena casa dentro da unidade, isto é, um espaço com sala, cozinha, quartos e banheiros. O efetivo deste módulo variava de dois a seis internos, não chegando a ultrapassar este número. $\mathrm{O}$ trabalho neste módulo foi exercido por cinco meses. O módulo 09 encontra-se desativado desde o mês de fevereiro de 2013.

O módulo seguinte foi o módulo 08. Este módulo, na Unire, é o módulo destinado à convivência protetora, conforme prevê a Resolução n. 119/2006 do Sinase. Nele são alojados os adolescentes e jovens que apresentaram dificuldades de convivência nos demais módulos da unidade e/ou que possuem atos infracionais ligados a crimes sexuais ou de grande repercussão midiática. O módulo 08 é vulgarmente chamado de "seguro" pelos internos e servidores da unidade. Além disso, pode ser considerado o destino final na Unire, pois depois dele só resta aos internos o isolamento no módulo 07, módulo disciplinar, ou a transferência para outra unidade de internação do sistema socioeducativo.

Após pouco mais de um ano no módulo 08, a profissional passou a atender os internos do módulo 03. Concomitantemente a sua chegada, houve uma reorganização no módulo 03, que passou a alojar dois diferentes grupos de internos: de um lado do módulo, 
adolescentes entre 12 e 17 anos de idade e, do outro lado, adolescentes da mesma faixa etária, no entanto, que se encontravam em situação de isolamento em outros módulos da unidade, principalmente, no módulo disciplinar. Houve dificuldades em trabalhar com os dois grupos ao mesmo tempo. Inserir o grupo de adolescentes em situação de isolamento nas atividades pedagógicas com os demais internos foi um obstáculo ao desenvolvimento da proposta socioeducativa.

Posteriormente, com uma nova mudança de módulo, a profissional passou a atuar no módulo 04. À época, o módulo 04 era o único módulo da unidade que alojava exclusivamente jovens entre 18 e 20 anos de idade em cumprimento de medida de internação. No decorrer do trabalho neste módulo, percebeu diferenças no comportamento e no tratamento dos jovens que ali estavam. A maioridade civil permitia que fossem, por vezes, não mais tratados como adolescentes respondendo a uma medida socioeducativa, mas como adultos. As ocorrências disciplinares passaram a ter outro significado, acarretavam não somente punições internas, mas desligamentos do sistema socioeducativo para o sistema prisional.

O contato com esta nova realidade ocasionou diversos questionamentos a respeito do papel profissional e do funcionamento do sistema socioeducativo, abrangendo a sua relação com o sistema prisional. E mais além, o caráter das ações e políticas do Estado capitalista em relação a estes jovens. Tais questionamentos a trouxeram de volta para o campo acadêmico e, especificamente, para o mestrado e a pesquisa.

\section{METODOLOGIA}

A escolha por pesquisar algo que se relaciona intrinsecamente com seu campo de trabalho estabelece, para além das obrigações de respostas metodológicas pertinentes a qualquer pesquisa, uma questão central: como ser pesquisadora dentro do próprio campo de trabalho? Por ter como campo de pesquisa uma instituição fechada e como amostra jovens sob responsabilidade do Estado, tive a necessidade de autorizações governamentais e judiciais para acesso aos dados. A burocracia envolvida na concessão destas autorizações, apesar de exigir tempo e paciência, não foi a maior dificuldade enfrentada por esta pesquisa. 
Em primeiro lugar, a metodologia teve de responder à dificuldade deste duplo papel: profissional e pesquisadora dentro de um mesmo espaço. Ressalta-se que a possibilidade de viver este duplo papel e realizar um estudo confiável existe. A prática profissional nos aproxima de realidades que, por vezes distintas das nossas, suscitam questionamentos e nos motivam a conhecer melhor seus limites e possibilidades de mudança. Cabe a nós, enquanto pesquisadoras, utilizar métodos confiáveis que eliminem as influências de nosso saber profissional e da nossa experiência cotidiana na produção de conhecimento científico. Ao considerar que o contato entre o pesquisador e o "pesquisado" possa acarretar implicações nos dados que comprometam a pesquisa, minha atuação enquanto pesquisadora no meu campo de trabalho mereceu atenção e exigiu estratégias metodológicas.

Este é um projeto de pesquisa de cunho qualitativo. As técnicas de pesquisa empregadas são a documental, a observação qualitativa e a memória do visto, com aplicação de métodos mistos de análise de dados. Entende-se aqui, por pesquisa qualitativa, aquela que privilegia análises interpretativas dos fenômenos sociais e que produz resultados não alcançados por meio de procedimentos estatísticos ou outros meios de quantificação que utiliza de diversas técnicas que privilegiam a interação entre pesquisador e objeto (CRESWELL, 2010; STRAUSS; CORBIN, 2008).

Na pesquisa qualitativa, a observação não se resume ao sentido da visão, mas envolve todos os demais sentidos. A observação qualitativa implica estar nas situações e desempenhar um papel ativo que envolve constante reflexão e atenção em relação aos detalhes dos eventos e das interações que se estabelecem no ambiente (SAMPIERI; COLLADO; LUCIO, 2013). Além da observação qualitativa durante a pesquisa de campo, a memória do visto ao longo desses cinco anos de trabalho foi um instrumento fundamental para compreender e construir o campo de pesquisa, mapeando as práticas e seus significados, os papéis e as relações entre os grupos. A pesquisa documental é outra técnica de pesquisa, que abrange o exame de documentos e demais registros produzidos por pessoas, grupos e organizações que envolvem o campo escolhido (SAMPIERI; COLLADO; LUCIO, 2013).

As etapas da pesquisa qualitativa - revisão de literatura, definição de amostra, coleta de dados e análise -, apesar de definidas, não se constituem em um processo linear. Elas são extremamente interativas e podem ocorrer em um constante movimento de idas e 
vindas até que se chegue a uma perspectiva mais geral (SAMPIERI; COLLADO; LUCIO, 2013). Sem esquecer-se desta perspectiva, são apresentadas nas próximas seções as etapas realizadas neste estudo.

\subsection{DEFINIÇÃO DE AMOSTRA}

O estudo foi conduzido nas unidades de internação do Distrito Federal que apresentam formalmente em seus efetivos jovens infratores, entre 18 e 20 anos de idade, em cumprimento de medida socioeducativa de internação. Existem sete unidades de internação de adolescentes e jovens infratores em funcionamento no Distrito Federal. Das sete unidades, três acautelam jovens, são elas: Unidade de Internação do Recanto das Emas (Unire), Unidade de Saída Sistemática (Uniss) e Unidade de Internação de Brazlândia (Uibra). A Unire é uma unidade de grande porte, com capacidade para 144 internos, por isso foi a instituição principal para desenvolvimento da pesquisa. Localizase na cidade do Recanto das Emas e, desde o mês de março de 2014, passou a atender exclusivamente jovens do sexo masculino entre 18 e 20 anos de idade (GDF, 2014b).

A Uniss foi inaugurada em dezembro de 2013 e também está localizada na RA do Recanto das Emas. Essa unidade é de pequeno porte, com capacidade para 80 internos e atende aos adolescentes e aos jovens que, em cumprimento da medida socioeducativa de internação, estão em usufruto do benefício de saídas sistemáticas (GDF, 2014a). Em relação à Unidade de Internação de Brazlândia (Uibra), seu funcionamento ocorre de forma temporária na Unidade de Internação de São Sebastião (Uiss) desde o mês de agosto de 2014. A Uibra, assim como a Unire, é destinada exclusivamente para jovens infratores, de 18 a 20 anos de idade, em cumprimento de medida socioeducativa de internação. Os jovens que são acautelados na Uibra permanecem alojados em três módulos cedidos pela Unidade de São Sebastião. Até a conclusão deste estudo, a inauguração da Uibra em Brazlândia ainda não havia ocorrido.

A unidade de análise desta pesquisa foi composta pelos dossiês dos jovens infratores em cumprimento de medida socioeducativa de internação que foram encaminhados a delegacias circunscricionais para registro de boletim policial após o envolvimento em ocorrências disciplinares e dos que foram desligados do sistema socioeducativo ao longo do cumprimento da medida, em virtude de apreensão no sistema 
prisional no ano de 2014. Cada jovem em cumprimento de medida socioeducativa de internação possui ao menos um arquivo institucional de caráter pessoal que permanece armazenado na própria unidade de internação em que o jovem se encontra. Nesses arquivos são anexados: sentenças, ofícios, petições dos jovens, relatórios técnicos, planos individuais de atendimento, ocorrências disciplinares, registros de passagens por delegacias e demais documentos pertinentes ao processo de cumprimento de medida socioeducativa. Esse arquivo pode receber o nome de pasta técnica, prontuário ou, simplesmente, arquivo. Nesta pesquisa, será chamado de dossiê "esse monturo de papéis produzido pela engrenagem policial, penal e tutelar" (DINIZ, 2015a, p. 575).

Além dos dossiês, o regime disciplinar, os efetivos diários, relatórios, estatísticas e controles de ocorrências disciplinares fornecidos pelos Núcleos de Informáticas e pelas Gerências de Segurança das unidades pesquisadas e informações contidas no Cadastro de Adolescentes da Internação (Cadin) - banco de dados em rede interna - foram utilizados como fonte de dados. Foi realizado ainda o levantamento dos marcos legais brasileiros que regulam, orientam, avaliam e dão diretriz à execução das medidas socioeducativas no Brasil, sendo eles: o Estatuto da Criança e do Adolescente (ECA), o Sistema Nacional de Atendimento Socioeducativo (Sinase), na forma da Resolução n. 119/2006 e da Lei n. 12.594/2012, o Plano Nacional de Atendimento Socioeducativo, o último Levantamento Anual dos/as Adolescentes em Cumprimento de Medida Socioeducativa e publicações físicas e online da Secretaria de Estado de Políticas para Crianças, Adolescentes e Juventude do Distrito Federal (Secriança), como o Projeto Político Pedagógico da Medida Socioeducativa de Internação no Distrito Federal e o livreto Construindo uma nova realidade.

Determinou-se, para o período de análise, o ano de 2014. Nesse ano, uma unidade é dedicada exclusivamente ao atendimento dos jovens entre 18 e 20 anos de idade em cumprimento de medida socioeducativa de internação no Distrito Federal e temos disponíveis dois importantes marcos regulatórios: a Lei n. 12.594/2012, que institui o Sinase, e o primeiro Plano Nacional de Atendimento Socioeducativo, publicado em 2013. Vale ressaltar que, por ter somente analisado o ano de 2014, existe um universo de jovens que foram para o sistema prisional em anos anteriores e ainda alguns que se encontravam no sistema prisional durante a execução do trabalho de campo. 
O universo de jovens em cumprimento de medida socioeducativa de internação é variável, em virtude do fluxo de decreto de novas internações, liberações da medida, evasões, progressões de medida, transferências e demais desligamentos. Considerando a característica de variação numérica da população deste estudo, o universo de análise foi extraído em cima do efetivo do primeiro dia útil do ano seguinte ao ano de referência, neste caso, dia 2 de janeiro de 2015. Nesse dia, havia um total de 308 jovens infratores entre 18 e 20 anos de idade em cumprimento de medida socioeducativa de internação no Distrito Federal.

\subsection{TRABALHO DE CAMPO}

Para consulta e acesso aos dados, foi necessária autorização da Vara de Execução de Medidas Socioeducativas (VEMSE) do Tribunal de Justiça do DF e Territórios (TJDFT) e da Secretaria de Estado de Políticas para Crianças, Adolescentes e Juventude (Secriança). Dessa forma, após autorização concedida pela VEMSE, foi encaminhado um projeto com a descrição do objetivo da pesquisa e dos dados que seriam coletados para submissão da Secretaria no mês de dezembro de 2014. Depois de concedidas as autorizações necessárias, o trabalho de campo ocorreu nos meses de janeiro, fevereiro, março e abril de 2015, nas três unidades de internação, em horário de expediente. Ressalta-se que o fato de ser servidora do sistema, mesmo que na qualidade de pesquisadora, apesar das curiosidades, proporcionou uma aceitação institucional mais imediata.

A coleta de dados abrangeu três fases: a) consulta aos efetivos e cadastros internos para identificar o número de ocorrências disciplinares e seus respectivos procedimentos e responsáveis para selecionar os dossiês; b) consulta aos dossiês para verificação das informações dos cadastros; c) aplicação de questionário nos dossiês selecionados. A partir dos efetivos e da consulta nos cadastros de rede interna, foram filtrados os internos com mais de 18 anos que apresentavam envolvimentos em ocorrências disciplinares e/ou que tinham sido desligados para o sistema prisional ao longo do ano de 2014. Feita a seleção dos jovens, o passo seguinte foi verificar se as informações disponíveis online estavam corretas, a partir do exame dos dossiês. 
Dentro de cada dossiê foi realizado o levantamento dos seguintes documentos: folha de identificação do jovem (idade, ato infracional, tempo de medida), sentenças de aplicação de medida socioeducativa de internação, certidão de passagens, relatórios técnicos, ocorrências disciplinares, relatórios de conselhos disciplinares, termos de declaração, registros de ocorrência policial e demais comunicações entre a execução do sistema socioeducativo, o sistema criminal e o Poder Judiciário, de modo geral, relativas ao processo de cumprimento de medida do jovem. Naqueles dossiês de jovens que se encontravam no efetivo do dia 2 de janeiro de 2015 e que foram desligados do sistema socioeducativo para o prisional ao longo do ano de 2014 foram aplicados um questionário.

\subsection{ANÁLISE DE DADOS}

O processo de coleta e de análise de dados ocorre simultaneamente em uma pesquisa qualitativa, apesar da necessidade do estabelecimento de um cronograma (CRESWELL, 2010). Após a coleta de dados, o primeiro passo analítico foi a realização de leituras completas e atentas das anotações e dos questionários, com intuito de iniciar o processo de codificação dos dados. A codificação foi baseada nos conceitos oriundos da revisão de literatura e das percepções a respeito do tema e no que emergiu dos dados (GIBBS, 2008). A partir da organização dos dados em um sistema classificatório inicial, a pesquisa utilizou de outras ferramentas analíticas que permitiram identificar categorias e desenvolvê-las. Segundo Strauss e Corbin (2008), as ferramentas analíticas, que são constituídas de mecanismos e técnicas que facilitam o processo de codificação, têm como objetivo aumentar a sensibilidade do pesquisador, a fim de que este reconheça tendências e inter-relações nos dados analisados.

As categorias encontradas no processo de codificação dos dados formaram matrizes de análise que combinam informações da coleta de dados quantitativos e qualitativos para que elas se tornem passíveis de interpretação e para melhor visualização (CRESWELL, 2010). Cada matriz deve conter uma pergunta-guia e categorias específicas a serem analisadas. Uma das matrizes conteve: 1. Idade do jovem; 2. Ato infracional e 3. Tempo de medida. Esta matriz permitiu considerações a respeito da duração média do tempo de privação de liberdade, sua relação com o ato infracional cometido e a variação da idade do jovem ao longo do processo socioeducativo. A 
segunda matriz elencou: 1. Idade do jovem ao ser apreendido no sistema prisional; 2. Ocorrência/Crime e 3. Tempo no sistema prisional. Esta matriz, por sua vez, permitiu estabelecer uma primeira relação entre o sistema socioeducativo e o sistema prisional. Como mencionado, dados quantitativos também foram levantados e expostos, como: o número e a frequência de ocorrências que tiveram o procedimento de encaminhamentos para delegacia, com exceção da Delegacia da Criança e do Adolescente (DCA), e o número de desligamentos para o sistema prisional.

Com os dados organizados, foi possível gerar uma teoria que se sustenta nos dados encontrados, mas que, a partir da relação com teorias já existentes, produz um novo conhecimento (STRAUSS; CORBIN, 2008). A Teoria Fundamentada, como o próprio nome revela, é uma teoria que surge baseada nos dados. A Teoria Fundamentada foi proposta por Barney Glaser e Anselm Strauss no livro The discovery of grounded theory, publicado em 1967 (SAMPIERI; COLLADO; LUCIO, 2013). É uma teoria que se faz coerente com os dados empíricos e as descobertas do trabalho de campo na busca para explicar um fenômeno social.

\subsection{PROCEDIMENTOS ÉTICOS}

Este estudo não foi submetido a nenhum comitê de ética em pesquisa. A submissão de pesquisa social a comitês não é obrigatória. Debora Diniz e Iara Guerriero (2008), ao discutirem o tema da ética em pesquisa, apontam alguns desafios que a pesquisa social traz ao atual sistema de revisão ética estabelecido no Brasil. Consideram que, mesmo após os debates entre os campos biomédicos e sociais sobre as atuais regulamentações e as técnicas metodológicas utilizadas nas pesquisas, as particularidades da pesquisa social foram pouco consideradas. Para as autoras, as técnicas qualitativas desafiam as regras de revisão dos comitês de ética em pesquisa brasileiros. O modelo de regulação brasileiro é ainda muito inspirado nas particularidades metodológicas e epistemológicas dos saberes biomédicos (DINIZ; GUERRIERO, 2008).

Contudo, a não submissão a um comitê de ética da presente pesquisa não significa ausência de cuidados éticos em relação aos sujeitos de pesquisa e aos dados coletados. A população deste estudo, jovens em cumprimento de medida socioeducativa de internação, apresenta-se como uma população vulnerável na condição de participantes de pesquisa. 
Entretanto, não houve a participação direta de seus membros, considerando que os dados foram obtidos por meio de pesquisa documental, de observação qualitativa e da memória do visto, o que reduziu os possíveis danos para essa população (ROGERS; BALLANTYNE, 2008).

$\mathrm{Na}$ descrição dos dados coletados nos dossiês foram omitidos ou alterados os nomes ou qualquer outro meio que possibilite a identificação de jovens, servidores e autoridades judiciárias envolvidas no processo de cumprimento de medida socioeducativa - sendo preservados e garantidos o sigilo e o anonimato de todas as partes envolvidas nos processos.

Por fim, ao avaliar que a maioria das pesquisas sociais envolve um risco mínimo, isto é, não ameaçam a integridade ou a segurança dos seus participantes durante a fase de coleta de dados, os maiores desafios éticos estão postos na fase de divulgação dos resultados (DINIZ; GUERRIERO, 2008). Foi assumido o compromisso com a Secretaria de Estado de Políticas para Crianças, Adolescentes e Juventude do Distrito Federal (Secriança) de devolver os achados de pesquisa, por meio da divulgação da dissertação, a despeito das possíveis repercussões negativas no ambiente de trabalho. 


\section{CAPÍTULO 1 \\ A EXPANSÃO PENAL DO ESTADO E O CASO BRASILEIRO}

[...] seria hipocrisia ou ingenuidade acreditar que a lei é feita para todo mundo em nome de todo mundo; que é mais prudente reconhecer que ela é feita para alguns e se aplica a outros, que em princípio ela obriga a todos os cidadãos, mas se dirige principalmente às classes mais numerosas e menos esclarecidas; que, ao contrário do que acontece com as leis políticas ou civis, sua aplicação não se refere a todos da mesma forma; que nos tribunais não é a sociedade inteira que julga um de seus membros, mas uma categoria social encarregada da ordem sanciona outra fadada à desordem [...] (FOUCAULT, 2014, p. 270).

O Estado é o detentor legal do poder de punir. No sistema capitalista, esse poder deve ser exercido "da forma mais funcional possível para aqueles que detêm o poder econômico" (NASCIMENTO, 2008). Loïc Wacquant (2007, 2011) e David Garland (2008) dedicaram-se a analisar a expansão penal do Estado nos Estados Unidos da América e sua relação com o neoliberalismo a partir do fim da década de 1970. Ambos concordam que a ascensão do punitivismo do Estado no país não é algo ocasional, mas sim um projeto político que reforça a figura do Estado e que se faz essencial para a manutenção e o crescimento do neoliberalismo. Garland (2008), a partir dos casos da Grã-Bretanha e dos Estados Unidos, identifica em sua análise uma nova política criminal baseada em uma mudança de cultura a partir do fim do século XX. Por outro lado, Wacquant (2011), ao analisar criticamente as influências de origem estadunidense sobre expansão do controle do crime na França ao longo dos últimos anos, considera que vivemos a passagem do Estado Social para o Estado Penal ou a hipertrofia do Estado Punitivo.

Ainda que as análises dos dois autores não tenham se dedicado ao caso brasileiro, o estudo da cena penal de países do capitalismo central contribui para a compreensão da realidade de demais países, dentre eles, o Brasil. Wacquant (2011), em uma nota aos leitores brasileiros feita em um de seus livros, avalia que a penalidade neoliberal, isto é, o conjunto de práticas, instituições e discursos relacionados à pena, é ainda mais devastador quando aplicado em países com altos índices de desigualdades sociais e de curta tradição democrática, como no caso brasileiro. Para o autor, o desenvolvimento do Estado Penal, a fim de dar respostas às consequências da desregulamentação da economia, da exclusão e precarização do trabalho assalariado e da pobreza relativa e absoluta de grande parcela do proletariado urbano brasileiro, equivale a "(r) estabelecer uma verdadeira ditadura sobre 
os pobres" (WACQUANT, 2011, p. 12, grifo do autor). Sem deixar de considerar as particularidades brasileiras, que envolvem nossa história, cultura e política, entender o que acontece ao nosso redor em relação a esse fenômeno contribui para pensar o que ocorre no Brasil.

Existe, de acordo com Wacquant $(2007,2011)$, relação direta entre a atrofia do Estado Social e a hipertrofia do Estado Penal nos Estados Unidos. Pode-se dizer uma relação de necessidade, uma vez que a redução e/ou extinção de um tem como contrapartida necessária o aumento e a prosperidade do outro. $\mathrm{O}$ autor defende a tese de que a expansão do braço penal do Estado naquele país vem para substituir seu braço social. Para ele, a ideia de enfraquecimento da potência estatal utilizada para justificar o fim do Estado de Bem-Estar Social é uma falácia ${ }^{2}$. O Estado, ao contrário do pensamento difundido pelo neoliberalismo, não se enfraqueceu, apenas mudou seus rumos (WACQUANT, 2007).

Wacquant (2007) considera que os Estados Unidos estão desenhando um novo tipo de Estado. Este Estado, chamado pelo autor de "Estado-centauro", possui uma cabeça liberal e um corpo autoritário que imprime a doutrina do laissez-faire às desigualdades sociais e suas causas, mas que, em relação às suas consequências, é paternalista e punitivo ao extremo. A pobreza se tornou um atentado intolerável contra o slogan estadunidense de "país das oportunidades". No entanto, a "guerra contra a pobreza" combatida por meio de programas sociais foi substituída pela guerra contra os pobres. A pobreza passa a ser uma questão de responsabilidade individual, assim como o crime. Os pobres ou os "detritos sociais", conforme Wacquant (2007) os descreve em um dos momentos do livro, acumulam-se nas cidades e causam indignação nos "cidadãos de bem", pois possuem um comportamento intolerável e representam uma ameaça cotidiana à segurança ${ }^{3}$. Assim, em contraposição às exigências de um Estado mínimo para o

\footnotetext{
${ }^{2}$ Estado de Bem-Estar Social é utilizado para descrever a atuação do Estado nos países capitalistas da Europa ocidental após a Segunda Guerra Mundial. Este período é marcado por um conjunto de intervenções públicas que o Estado assumiu para assegurar proteção social a todos. No caso do Brasil, o Estado Social nunca chegou a se consolidar, visto o fato de não termos alcançado o patamar do pleno emprego e os padrões de proteção europeus só abarcaram os trabalhadores vinculados ao mercado formal de trabalho, o que representa apenas uma parcela dos trabalhadores brasileiros. Ver mais sobre o Estado de Bem-Estar Social e as particularidades da política social no Brasil em: BEHRING, Elaine Rossetti; BOSCHETTI, Ivanete. Política social: fundamentos e história. São Paulo: Cortez, 2006.

${ }^{3} \mathrm{O}$ termo "cidadãos de bem" surgiu no jornal norte-americano The Good Citizen, do início do século XX (<www.confradewashington.com.br〉). No Brasil, o termo é utilizado tradicionalmente pelo campo da direita conservadora, que faz uma divisão da sociedade entre "cidadãos de bem" e "vagabundos". Os ditos “cidadãos de bem" são as pessoas consideradas cidadãs, que pagam seus impostos em dia, respeitam as leis,
} 
mercado, os "cidadãos de bem" passam a exigir um Estado máximo na questão da segurança, o que legitima o avanço do Estado Penal.

Wacquant (2007), ao comparar as taxas relativas à criminalidade estadunidense, verificou que elas se mantiveram constantes, tendo, inclusive, uma queda nos últimos anos. Dessa forma, a ascensão punitiva estatal nos Estados Unidos, ao longo das últimas três décadas, não estaria relacionada com o aumento da criminalidade no país. O autor relaciona o tratamento punitivo da insegurança e da marginalidade sociais, isto é, de uma marginalidade persistente, enraizada no desemprego, no subemprego e no trabalho precário, como consequências lógicas das políticas neoliberais - redução dos gastos públicos, privatização, financeirização, flexibilização do trabalho assalariado e redução da proteção social - impostas pelos fundos internacionais como condição de ajuda financeira (WACQUANT, 2007, 2011).

Há duas décadas, órgãos dos Estados Unidos encarregados de promover o "rigor penal", por meio de uma nova crença comum punitiva em favor de "menos Estado" no controle do capital e na utilização da mão de obra e "mais Estado" na contenção e mascaramento das consequências sociais da desregulamentação do trabalho assalariado e do desmantelamento da proteção social, conseguiram quadruplicar a população carcerária daquele país em um período de estagnação e seguinte recuo da criminalidade (WACQUANT, 2011). Um novo governo da insegurança social - que dirige a conduta dos homens e das mulheres vítimas da desregulamentação econômica que foram empurrados da assistência social para empregos precários e faz do encarceramento uma possibilidade de controle ainda maior sobre eles, sobretudo, daqueles que são negros e negras - se forma nos Estados Unidos e se difunde pelo resto do mundo (WACQUANT, 2007).

Os Estados Unidos possuem o maior número de pessoas encarceradas do mundo. No que diz respeito ao aumento no encarceramento de pessoas, é possível encontrar similaridades assustadoras entre o Brasil e os Estados Unidos. Na mesma lista em que os Estados Unidos ocupam a primeira posição, o Brasil ocupa a quarta. Em uma década, de 1997 a 2007, a população carcerária brasileira teve aumento de 247\%, passamos de 170.000 presos, em 1997, para 420.000 presos, em 2007 (NASCIMENTO, 2008). Em

são incapazes de cometer qualquer tipo de crime e que lutam para vencer na vida de maneira digna (<consciência.blog.br〉). O uso do termo pode também ser feito com ironia, de forma a criticar a hipocrisia que o envolve, assim como foi feito pelo autor Loïc Wacquant. 
2014, a população carcerária brasileira chegou a 607.700 presos, tendo um aumento de $80 \%$ em números absolutos se compararmos em relação ao ano de 2004 . Ao dividir o número de presos pela população brasileira, a taxa de encarceramento entre 2004 e 2014 cresceu 61,8\% (BRASIL, 2015a). Desde o ano de 2002, a cada cem mil habitantes o número da população carcerária cresce em média $10 \%$ ao ano, sendo que, esse ritmo é acompanhado por todas as Unidades da Federação (BRASIL, 2015a).

Para Wacquant (2007, p. 36), as sanções individuais, ao não incidirem sobre os "mecanismos geradores da conduta delinquente", servem somente para ressaltar a autoridade do Estado e a força de seu braço penal. Entretanto, não só o encarceramento em massa é consequência desse novo senso comum penal que dirige o avanço punitivo do Estado. A passagem do welfare para o workfare nos Estados Unidos permitiu ainda a este novo Estado, além da contenção punitiva, a vigilância e o controle constante daqueles que antes eram alvos da política social (WACQUANT, 2007). Wacquant (2007, p. 231) ressalta que:

[...] a estatística penitenciária ainda assim subestima gravemente a dominação que as instituições judiciárias exercem sobre as populações localizadas nas regiões inferiores do espaço social estadunidense, pois não leva em conta a expansão espetacular dos meios indiretos de vigilância e de controle dos quais as autoridades são dotadas, a fim de regular as frações desqualificadas da classe operária na era da generalização do trabalho precário e da retração das proteções oferecidas pelo Estado.

Teorias de controle de diversos tipos - sociais, situacionais e autocontroles -, que consideram a delinquência não como um problema de privações econômicas, mas de controle inadequado (GARLAND, 2008), dominam a criminologia atual e as suas respectivas políticas. Dessa forma, o reconfigurado campo do controle do crime torna-se mais do que uma mudança na resposta da sociedade ao crime, representa também novas práticas relacionadas ao controle de comportamentos e ao modo de fazer justiça. Assim, este campo dispõe de dois novos tipos de ação: "uma estratégia de adaptação, que enfatiza a prevenção e a parceria, e uma estratégia do Estado soberano, que postula maior controle e punições expressivas" (GARLAND, 2008, p. 312, grifo do autor). No entanto, essa necessidade de mais controle não é para todos. Esse excessivo controle é exercido sobre a população pobre. Em contraposição à cultura pregada pela pós- 
modernidade, o novo conservadorismo direciona sua disciplina aos pobres. Estes devem ser mais disciplinados.

Para Garland (2008, p. 419), "o efeito combinado de políticas 'neoliberais' e 'neoconservadores' - de disciplina do mercado e de disciplina moral - tem sido o de criar uma situação na qual mais e mais controles são impostos aos pobres". O autor, ao tratar dos desdobramentos nos últimos 30 anos no campo da política criminal, procura identificar quais forças culturais, econômicas, sociais e políticas fazem pano de fundo ao atual contexto do campo de controle do crime. Para isso, opta por se concentrar no conjunto das respostas sociais dadas ao crime. Garland (2008) defende o argumento de que a situação atual, em termos de controle do crime, foi moldada por duas forças sociais fundamentais: o modo especial de organização social da pós-modernidade do século XX e a economia de mercado ${ }^{4}$.

O modo de organização da pós-modernidade cria "um grupo de riscos, inseguranças e problemas relacionados ao controle" (GARLAND, 2008, p. 33) que passam a definir as respostas dadas ao crime. Antes, no previdenciarismo penal, as penas visavam à reabilitação, pois seu objetivo encontrava-se na promoção do bem-estar social, por meio da (re) inclusão do indivíduo na sociedade. O crime, na visão da criminologia correcionalista, era visto como um problema social que exigia soluções sociais (GARLAND, 2008). Hoje, para as novas criminologias, o crime se tornou um fato social normal da sociedade moderna, uma simples questão de oportunidade. Por ser uma escolha, a polícia desempenha um papel central sob o seu controle (GARLAND, 2008). A origem dessa mudança está para além da naturalização das taxas de criminalidade ou do descrédito dado ao previdenciarismo penal e na criminologia correcionalista, mas na pós-modernidade e nas suas exigências: exigências econômicas, políticas e culturais que foram e são necessárias para seu desenvolvimento (GARLAND, 2008).

O modelo do previdenciarismo penal ligado a uma forma específica de Estado e a uma determinada estrutura de relações de classe passa a ser questionado. A normalidade

\footnotetext{
${ }^{4}$ Garland (2008) denomina de pós-modernidade do século XX o caráter específico de relações sociais, econômicas e culturais que emergiram nos Estados Unidos, na Grã-Bretanha e em outros lugares do mundo, desenvolvido no último terço do século XX como reação à crise do Estado de Bem-Estar. Para o autor, o termo "pós-modernidade do século XX" denota uma fase histórica do processo de modernização que ainda não teve um fim ou mesmo ápice, mas que é parte de uma dinâmica centenária sem sinais de que está prestes a terminar. Garland diz que a escolha pelo termo é por conveniência, e por isso realiza ressalvas em relação ao seu uso para generalizações.
} 
da alta taxa de criminalidade e a baixa efetividade da justiça criminal dão origem ao que o autor chama de "novo dilema criminológico". Em resposta a esse novo dilema, uma formação cultural denominada de "complexo do crime" da pós-modernidade reorganiza antigas estruturas para além da criação de novas instituições. As velhas instituições ligadas ao controle do crime têm suas práticas redefinidas, sendo assim, a mudança no campo do controle do crime, isto é, neste complexo de práticas e instituições, das mais simples e cotidianas às mais formais e excepcionais, usadas atualmente como respostas sociais dadas ao crime, ocorre mais no nível cultural do que propriamente nas instituições (GARLAND, 2008).

As atuais políticas de controle do crime, para o autor, são social e culturalmente condicionadas. A preocupação primordial da criminologia correcionalista, considerada hoje como a velha criminologia, estava em disciplinar e punir os delinquentes. A nova criminologia tem por objetivo o controle, não só do indivíduo delinquente, mas das "situações criminogênicas". Essas situações são oportunidades, produtos e locais considerados propícios à prática de algum crime (GARLAND, 2008). Cria-se uma sociedade do controle.

André Nascimento (2008) considera que ainda não estamos vivendo no Brasil os fenômenos da pós-modernidade penal na intensidade e vigor dos Estados Unidos e da Grã-Bretanha conforme relata Garland (2008). Entretanto, Nascimento (2008) avalia que o avanço penal do Estado no Brasil, e na América Latina como um todo, encontra-se em processo de marcha a caminho do que ocorre naqueles países. Devido à posição marginal e dependente do Brasil na ordem mundial do sistema capitalista, os fenômenos que ocorrem nos países de primeira ordem podem se desdobrar por aqui ou se transformarem em tendências a serem seguidas, considerando que é corriqueira a importação de políticas e práticas dos países centrais por nossas instituições e elites latinas. Porém, mesmo importando, a intensidade por aqui nunca será a mesma de fora. Primeiro, por causa das diferenças entre as tradições jurídicas norte-americana e latina; segundo, por uma questão orçamentária - o orçamento dos países latino-americanos destinado às políticas penais de combate ao crime ainda é modesto, considerando que a área social nesses países ainda apresenta muita demanda por investimentos; e, por último, junto com o baixo orçamento, nossas instituições penais se encontram em um estado lastimável, de forma a afastar a realocação de recursos na implementação de medidas repressivas em detrimento dos investimentos em setores básicos (NASCIMENTO, 2008). 
Dessa forma, no caso brasileiro, a expansão do punho penal é acompanhada pela expansão social. No Brasil, o investimento pelo governo federal em construção de vagas para o sistema prisional bateu recorde no último ano, chegando à cifra de mais de 1,1 bilhão de reais (BRASIL, 2015a). Incluindo todos os entes federados, houve crescimento de $16,5 \%$ dos gastos nacionais com segurança pública em 2014, comparativamente ao ano anterior. Passamos de pouco mais de 61 bilhões de reais, em 2013, para pouco mais de 71 bilhões de reais, em 2014. Em relação ao PIB, foi alocado na área de segurança pública praticamente o mesmo percentual do PIB $(1,29 \%)$ verificado nos países europeus (1,3\%) (SAPORI, 2015). Contudo, a área de segurança pública ainda possui um PIB menor do que os gastos na área social no Brasil.

Em meio a isso, Wacquant (2007) identifica um forte elo entre as políticas sociais e penais. $\mathrm{O}$ autor denomina de panoptismo social a atuação estatal que, sob a justificativa de garantir uma política de bem-estar social, submete os pobres "a uma vigilância punitiva cada vez mais precisa e penetrante" (WACQUANT, 2007, p. 56), em que os serviços sociais passam a dar continuidade ao aparelho penal. Assim, Wacquant (2007) propõe que existe uma ligação entre as transformações das políticas sociais e as das políticas penais e, com isso, o proletariado estaria duplamente submetido ao controle dos setores assistencial e punitivo do Estado. Em um único dispositivo, agrega-se a sanção penal e a supervisão do bem-estar para capturar culturalmente e controlar o comportamento das populações pobres (WACQUANT, 2007).

A regulação das famílias pobres não passa mais somente pelo braço maternal e social do Estado, mas "se apoia também no braço viril e controlador do Estado penal" (WACQUANT, 2007, p. 44). Diante disso, é preciso considerar tanto as modificações nas políticas sociais quanto as das políticas penais para compreender o quanto os pobres estão submetidos ao controle do setor assistencial e do setor penitenciário do Estado (WACQUANT, 2007). O Estado sempre foi penal. A diferença está no grau. Ele não deixou de punir em nenhum momento, mas agora está punindo de forma mais intensa, em diversos espaços e por distintos meios (GARLAND, 2008). 


\section{AS PARTICULARIDADES DO CASO BRASILEIRO}

\subsection{A REALIDADE PELOS NÚMEROS}

A discussão a respeito do campo de controle do crime no Brasil apresenta algumas dificuldades de abordagem devido às características dos dados sobre a criminalidade no país. Não há um padrão nacional seguido pela produção de dados, além de uma ausência de estatísticas oficiais. Marcelo Durante (2009) considera que, devido ao grande período da história brasileira de forte oscilação entre a autonomia estadual e o controle federal, a gestão das ações e políticas de segurança pública no Brasil ocorreu de forma desarticulada entre os seus diversos órgãos. Somente a partir da década de 1990, devido à cobrança popular, o governo federal começa a articular suas ações e políticas na área de segurança pública. Em 1995, foi criada a Secretaria de Planejamento de Ações Nacionais de Segurança Pública (Seplanseg), do Ministério da Justiça (MJ), transformada, em setembro de 1997, na atual Secretaria Nacional de Segurança Pública (Senasp). Em 2000, é instituído o Fundo Nacional de Segurança Pública (FNSP) e são anunciadas as primeiras diretrizes e propostas de um Plano Nacional de Segurança Pública (PNSP), "cujo objetivo era articular ações de repressão e prevenção da criminalidade no país" (DURANTE, 2009, p. 48).

Desde 2003, a Senasp vem investindo esforços na implantação do Sistema Único de Segurança Pública (Susp). O Susp seria um sistema único criado para integrar as ações federais, estaduais e municipais na área da segurança pública e da justiça criminal que hoje encontram-se ainda dispersas (DURANTE, 2009). O Projeto de Lei n. 3734/2012, que cria o Susp, foi aprovado na Comissão de Educação da Câmara em dezembro de 2014, mas resta ser analisado por mais três comissões. Até o momento, o PL encontra-se em discussão no Congresso Nacional (BRASIL, 2014d). Para além da proposta do Susp, existe um esforço do TCU para que a divulgação de estatísticas por parte dos diversos atores do governo federal se torne uma obrigação (DURANTE, 2009). Por outra via, desde o ano de 2004, o Departamento Penitenciário Nacional (Depen), ligado ao Ministério da Justiça, sintetiza informações sobre os estabelecimentos penais e a população prisional e as divulga por meio de um relatório, denominado de Levantamento de Informações Penitenciárias - Infopen. O último levantamento foi divulgado em 2015, com dados consolidados até o primeiro semestre de 2014. Para este último relatório, 
foram realizadas diversas alterações na metodologia e no instrumento de coleta de dados, com intuito de aprimorar o documento. Além das mudanças metodológicas, foi a primeira vez que os dados foram publicados em formato aberto (BRASIL, 2015a). Em meio a estes avanços, o próprio documento faz ressalvas sobre o seu alcance e conclusões, considerando as dificuldades de coleta de dados que teve em alguns Estados da Federação, como no caso de São Paulo.

Contudo, apesar da ausência de alguns dados, a situação carcerária apresentada coloca-se como uma das questões mais complexas da realidade social brasileira (BRASIL, 2015a). O retrato do sistema prisional apresentado nesse levantamento mostrase caótico. O número de pessoas presas em 2014 é 6,7 vezes maior que em 1990. Desde o ano de 2000, a população prisional cresceu, em média, $7 \%$ ao ano, totalizando um crescimento de $161 \%$. Este valor é dez vezes maior que o crescimento do total da população brasileira, que apresentou aumento de apenas $16 \%$ no período, em uma média de $1,1 \%$ ao ano (BRASIL, 2015a). O crescimento acelerado da população carcerária brasileira é contrário à trajetória vivenciada pelos demais países de maior contingente prisional do mundo. Nos últimos seis anos, os Estados Unidos, a China e, principalmente, a Rússia, estão reduzindo seu ritmo de encarceramento. O Brasil registrou, entre os anos de 1995 e 2010, a segunda maior variação na taxa de aprisionamento dentro do grupo dos 50 países com maior população prisional. Um crescimento na ordem de 136\%. Se essa tendência for mantida, de acordo com as previsões, a população encarcerada do Brasil ultrapassará a da Rússia em 2018, em 2022 ultrapassará a marca de um milhão de indivíduos e, em 2075, uma em cada dez pessoas estará em situação de privação de liberdade (BRASIL, 2015a).

Outra situação alarmante brasileira diz respeito ao alto número de pessoas encarceradas sem julgamento. O Brasil exibe a quinta maior taxa de presos sem condenação (BRASIL, 2015a). Do total de pessoas encarceradas no Brasil, aproximadamente quatro, entre dez (41\%), estavam presas sem ainda terem sido julgadas e a maioria dos presos provisórios (60\%) está detida por prazo superior à duração razoável do processo, isto é, por mais de 90 dias (BRASIL, 2015a). Tal situação não se restringe ao Brasil e pode ser observada em outros países. Segundo relatório de 2014 do Centro Internacional de Estudos Prisionais (ICPS, na sigla em inglês), cerca de três milhões de pessoas no mundo estão presas provisoriamente e, em mais da metade dos países, observa-se que há tendência crescente no uso dessa medida (BRASIL, 2015a). 
Essa tendência expõe um grande número de indivíduos às consequências do aprisionamento, além de contribuir para a superlotação das prisões (BRASIL, 2015a).

A situação de superlotação das prisões também faz parte da realidade brasileira. As prisões do país abrigam quatro pessoas ou mais por vaga disponível. A taxa de ocupação média das prisões brasileiras é de $161 \%$, ou seja, em um espaço destinado para dez pessoas, existem por volta de 16 presas (BRASIL, 2015a). Em relação ao perfil dessas pessoas que estão presas, na maioria das vezes, ainda em caráter provisório em prisões superlotadas, a maior parte é formada por jovens, negros, com baixa escolaridade e de baixa renda. $\mathrm{O}$ encarceramento elevado da população jovem e negra é um fenômeno observado em todo o país. Ao comparar o perfil etário da população prisional com o perfil da população brasileira em geral, observa-se que a proporção de jovens é maior no sistema prisional que na população em geral - 56\% da população prisional é composta por jovens e essa faixa etária compõe apenas $21,5 \%$ da população total do país (BRASIL, 2015a). Em relação à raça/cor, a proporção de pessoas negras presas é de dois a cada três, sendo a porcentagem de pessoas negras, no sistema prisional, de $67 \%$, e na população brasileira, em geral, de 51\% (BRASIL, 2015a).

A ligação entre a discriminação racial e a justiça criminal se confirma nos números e é objeto de análise de diversos autores. Estudos sobre o tema revelam que os negros compõem o grupo que recebe tratamento mais severo pelas autoridades policiais e instituições de justiça. De acordo com os resultados da pesquisa de Sérgio Adorno (1996), a vigilância policial sobre a população negra é maior do que sobre a população branca, tendo em vista ter havido maior incidência de prisões em flagrante para réus negros $(58,1 \%)$ comparativamente a réus brancos $(46,0 \%)$. Jacqueline Sinhoretto (2015, p. 85) afirma que o investimento no modelo atual de encarceramento representa "uma forma de investir muito dinheiro da sociedade para aumentar a desigualdade racial". Entre os anos em que ocorreu a multiplicação do número de presos no país, o encarceramento de negros foi mais acelerado que o de brancos (SINHORETTO, 2015).

A frequência, por tipo penal, de crimes tentados ou consumados pelos quais as pessoas presas foram condenadas ou aguardam julgamento no Brasil, não é um dado concluído. De acordo com o Levantamento do Depen, grande parte dos estabelecimentos não informou o número de crimes relativos às pessoas presas ou forneceu a informação de modo incompleto, sendo que os dados divulgados referem-se somente a 188.866 
presos. Nessa amostra, o tráfico de entorpecentes é o crime de maior incidência, respondendo por $27 \%$ dos crimes informados, seguido por roubo, com $21 \%$. Já o homicídio corresponde a 14\% dos registros e o latrocínio a 3\% (BRASIL, 2015a).

Dessa forma, torna-se complicado analisar a evolução da taxa de criminalidade brasileira em relação a todos os tipos penais. A única variação disponível é em relação às taxas de criminalidade referentes a crimes violentos. Ocorreu significativo aumento na taxa de criminalidade violenta do país, particularmente nos casos de violência com uso de arma de fogo e no número de homicídios. Considera-se que um dos indicadores mais consistentes do aumento da criminalidade violenta no Brasil nas últimas décadas é a evolução da incidência de homicídios (BRASIL, 2003). O Brasil apresenta níveis acima da média mundial em relação a este crime. Nos últimos 30 anos, a taxa de homicídios no Brasil cresceu 124\%. Entre 1980 e 2010, mais de um milhão de pessoas foram assassinadas. Enquanto na década de 1980 foram registrados 11,7 homicídios por 100 mil habitantes, em 2010 o índice chegou a 26,2 - um aumento médio de $2,7 \%$ ao ano (WAISELFISZ, 2012).

Grande parte das vítimas destes homicídios são pessoas pobres, negras e jovens. $\mathrm{O}$ Brasil ocupa o terceiro lugar em relação à taxa de homicídios de adolescentes de 15 a 19 anos, dentre 85 países analisados (WAISELFISZ, 2012). De acordo com o Mapa da Violência, os homicídios representam quase metade das causas de mortes de jovens de 16 e 17 anos no Brasil (WAISELFISZ, 2015a). Assim como a população carcerária, os adolescentes do sexo masculino, negros e com baixa escolaridade são as principais vítimas de homicídio no país. Em relação à incidência de homicídios, é alto o percentual de ocorrências envolvendo o uso de arma de fogo, mais alto ainda quando as vítimas são jovens negros. Entre os anos de 1980 e 2012, a população brasileira teve um crescimento em torno de $61 \%$. Nesse período, os homicídios por arma de fogo cresceram $387 \%$, contudo, entre os jovens, esse percentual chegou a 460\% (WAISELFISZ, 2015b).

Em meio às dificuldades de acesso aos dados nacionais, os números disponibilizados apontam para um alto nível de violência letal no país. Anualmente, ocorrem quase 60 mil mortes violentas intencionais no Brasil. Dentre essas mortes, o número de mortos decorrentes de intervenção policial é a segunda causa de mortes violentas intencionais, sendo que, em 2014, superou em 46,6\% o número de latrocínios (LIMA; BUENO, 2015). De acordo com o $9^{\circ}$ Anuário Brasileiro de Segurança Pública 
(2015), em nenhum país do mundo, sem guerra declarada, mais seres humanos mataram outros seres humanos do que no Brasil no ano de 2014.

Para Pedro Abramovay (2015), a única explicação razoável para esse estado de indiferença diante de tanto horror e para a aceitação de uma polícia tão letal é o fato de que os mortos são vidas descartáveis por serem quase todos pobres, negros e jovens. Cabe ressaltar que, dentre essas vidas descartáveis, estão 398 policiais mortos em 2014 (ABRAMOVAY, 2015). Wacquant (2011) se assusta com a questão da violência institucional no Brasil, representada pela violência policial e pela situação apavorante das prisões no país. Para o autor, a insegurança criminal no Brasil é agravada pela intervenção das forças da ordem. O uso da violência letal pelas polícias brasileiras seria parte de uma tradição nacional de concepção hierárquica e paternalista de cidadania que controla os miseráveis pela força ao longo dos séculos. Para Wacquant (2011, P. 11), "a manutenção da ordem de classe e a manutenção da ordem pública se confundem" no Brasil.

Em relação às prisões brasileiras, o autor as considera como "campos de concentração para pobres”. Como depósitos de dejetos sociais, Wacquant (2011, p. 13) as avalia como as "piores jaulas do Terceiro Mundo". As péssimas condições das instituições prisionais e o desrespeito às normas nacionais e internacionais de tratamento ao preso, incluindo os casos de tortura sistemática que ocorrem nas prisões brasileiras, integram importantes relatórios internacionais. Assim, a ideia de que políticas penais mais enérgicas podem ser efetivas na redução de homicídios representa uma falácia. Os últimos 15 anos foram marcados tanto pelo aumento no número de brasileiros assassinados como no número de pessoas encarceradas (ABRAMOVAY, 2015).

\subsection{O ESTADO PENAL BRASILEIRO}

Garland (2008) e Wacquant $(2007,2011)$ analisaram o avanço penal do Estado em uma conjuntura particular, que envolve uma forma própria de Estado, com estrutura de classes e políticas econômicas e sociais específicas. Diante do atual quadro do sistema prisional brasileiro e das elaborações dos dois autores, discute-se se o que ocorre no Brasil já constitui o Estado Penal brasileiro. Vinício Martinez e Fátima Santos (2009) lembram que, na América Latina, a história política sempre se esbarra na história policial. 
O Estado Penal, como uma espécie de Estado repressor, sempre se colocou à espera de movimentos que permitissem transpor as garantias legais e morais das instituições democráticas. Dessa forma, para os autores, o Estado Penal, no Brasil, e de forma geral na América Latina, mais do que uma influência estadunidense, tem origem e raízes antidemocráticas (MARTINEZ; SANTOS, 2009). De acordo com Martinez e Santos (2009, p. 219):

[...] evoluímos: do chicote escravocrata, ao cárcere de segurança máxima; do exílio à prisão superlotada; dos mucambos às celas fétidas; do terreiro ou do pelourinho a muitos Carandirus que ainda resistem; do cortiço à marginal; de escravo a favelado e daí a encarcerado; de pobre a criminoso; de escravo ou "sem-nada" a "Sem-Terra" ou "Sem-Teto", "sem comida", "sem dignidade", "sem nada", mas com muita punição e penas severas".

Nascimento (2008) considera as particularidades da formação histórica e política do Brasil para analisar as políticas penais do Estado. Para o autor, o processo tardio de industrialização e o cenário político turbulento devido à ditadura militar interferem no atual quadro do Brasil. É somente a partir da redemocratização do país na década de 1980 que o tratamento penal dos conflitos sociais passa a se tornar mais severo. A crise econômica traduzida pela baixa nas taxas de juros, na queda no consumo e na baixa produtividade do trabalho que assolou os países do norte nos anos de 1970 chegou tardiamente no Brasil (BRISOLA, 2012). No momento em que os países desenvolvidos, dentre eles os Estados Unidos, entravam em um novo ciclo de crise, o Brasil vivia o "milagre econômico", (NASCIMENTO, 2008).

Contudo, o milagre brasileiro não foi para todos. Em relação à política penal do Estado brasileiro durante o regime militar, os níveis de encarceramento chamavam mais atenção pela qualidade do crime do que pela quantidade de encarcerados. Foi na ditadura militar que o discurso do inimigo interno, que neste caso era representado pelo comunista revolucionário, ganhou força. Para alguns autores, hoje essa figura encarna-se no traficante de drogas (NASCIMENTO, 2008). Passada a ditadura militar, o período de redemocratização no Brasil é marcado por uma forte reforma administrativa. Esta

\footnotetext{
5 O milagre econômico brasileiro compreende os anos de 1965 e 1975. Nesse período, a economia brasileira cresceu significativamente. A produção industrial aumentou em volume, as exportações cresceram, o nível de investimentos também aumentou, a inflação esteve sob controle e as taxas de desemprego se mantiveram baixas (NASCIMENTO, 2008).
} 
reforma foi feita por meio de três frentes: privatizações de importantes empresas estatais, delegação à iniciativa privada dos serviços públicos essenciais e terceirização de funções auxiliares. A partir dessas alterações, as relações de trabalho entram em processo de flexibilização e, consequente, precarização. Os trabalhadores que não conseguem nem ao menos vender sua força de trabalho de forma precária são empurrados para as periferias dos grandes centros urbanos e, posteriormente, para as prisões superlotadas (NASCIMENTO, 2008).

Tendo em vista o atual contexto de crise do capital vivenciado agora também por aqui, a emergência do Estado Penal não se faz somente nos países centrais, como no exemplo dos Estados Unidos, França e Grã-Bretanha, mas nos periféricos, como no caso do Brasil (BRISOLA, 2012). Conforme Wacquant (2011), as estratégias de superação da crise contemporânea de acumulação do capital adotadas pelas sociedades capitalistas têm impactos muito maiores sobre aqueles com profundas desigualdades sociais. Dessa forma, o avanço do Estado Penal, no Brasil, apresenta-se ainda mais impactante, considerando a pobreza alarmante do país e os altos índices de desemprego (BRISOLA, 2012).

Para Nascimento (2008), dois elementos essenciais sustentam a ascensão do Estado Penal e a consequente criminalização da pobreza no Brasil: 1. a mídia, que, por vezes, associa a prática de violência às condições de pobreza, etnia e território, no caso, aos pobres negros moradores das periferias e favelas dos grandes centros urbanos; e 2. as formas como os setores dominantes fomentam o medo, a insegurança e o desamparo para exigir do Estado práticas mais repressivas. O papel dos meios de comunicação na disseminação do medo do crime é apontado tanto por Garland (2008) quanto por Wacquant (2007, 2008). A mídia alavanca o poder punitivo estatal por meio da disseminação do medo do crime e do discurso da solução penal para a resolução de todo e qualquer tipo de conflito social e, diante da particularidade brasileira de ausência de dados, esse papel ganha ainda mais força. 


\section{CAPÍTULO 2 \\ INTERNAÇÃO: ENTRE A PUNIÇÃO E A RESSOCIALIZAÇÃO}

\section{A MEDIDA SOCIOEDUCATIVA DE INTERNAÇÃO}

A internação de adolescentes e jovens infratores é uma das seis medidas socioeducativas previstas no Brasil. O caráter pedagógico no tratamento de adolescentes e jovens que cometeram algum tipo de ato infracional aparece há 25 anos no país, a partir da promulgação do Estatuto da Criança e do Adolescente (ECA) em 1990. Isto é, o objetivo de ressocializar adolescentes e jovens infratores tem história recente no Brasil. O ECA (Lei n. 8.069/1990) foi um marco para o desenvolvimento das atuais políticas de atenção à infância e adolescência no país. Foi a partir de sua vigência que o Estado brasileiro passou a aplicar medidas socioeducativas aos "adolescentes em conflito com a lei”, antigos “menores delinquentes”. A Lei n. 8.069, de 13 de julho de 1990, que dispõe sobre o Estatuto da Criança e do Adolescente, trata em seu Livro II - Parte Especial - da Política de Atendimento dos direitos da criança e do adolescente e, mais especificamente em seu Título III, do atendimento para aqueles adolescentes autores de ato infracional (BRASIL, 1990).

A partir dos princípios, concepções e objetivos dispostos no ECA, começa-se a delinear a atual política pública específica para o atendimento de adolescentes e jovens infratores, a política da socioeducação. No âmbito deste processo, tem-se a construção do Sistema Nacional de Atendimento Socioeducativo (Sinase). O Sinase foi primeiramente instituído pela Resolução n. 119/2006, do Conselho Nacional dos Direitos da Criança e do Adolescente (Conanda) e, somente no ano de 2012, foi aprovado na forma de lei. A Lei n. 12.594, de 18 de janeiro de 2012, que institui o Sinase, em seu art. $1^{\circ}$, o descreve como

o conjunto ordenado de princípios, regras e critérios que envolvem a execução de medidas socioeducativas, incluindo-se nele, por adesão, os sistemas estaduais, distrital e municipais, bem como todos os planos, políticas e programas específicos de atendimento a adolescente em conflito com a lei (BRASIL, 2012). 
O Sinase tem o papel de regulamentar a forma como o poder público, por meio de seus diversos órgãos e agentes, deverá prestar o atendimento especializado aos quais adolescentes infratores têm direito. Ele abrange desde a parte conceitual da execução das medidas socioeducativas até a forma de financiamento do sistema socioeducativo (DIGIÁCOMO, 2012). No Sinase, em sua forma de lei, as medidas socioeducativas possuem, resumidamente, três objetivos: a responsabilização do adolescente em relação às consequências do ato infracional praticado, priorizando a sua reparação; a integração social do adolescente e a garantia de seus direitos individuais e sociais; e a desaprovação da sua conduta infracional (BRASIL, 2012). Para alguns autores e sujeitos envolvidos com a temática do sistema socioeducativo, o objetivo fim do Sinase seria a efetiva implementação de uma política pública especificamente destinada ao atendimento de adolescentes e jovens infratores (DIGIÁCOMO, 2012).

De acordo com os últimos levantamentos nacionais disponíveis, a taxa de restrição e privação de liberdade, no Brasil, com predominância para a internação, cresce de forma constante e regular desde 2010 (BRASIL, 2015b). O marco situacional geral do Plano Nacional de Atendimento Socioeducativo aponta um total de 448 unidades socioeducativas no país, sendo que a maioria - 166 unidades (37\%) - são destinadas exclusivamente à internação e internação provisória e 162 (36\%) executam ao mesmo tempo mais de uma medida socioeducativa, desde internação a atendimento inicial (BRASIL, 2013a). O Distrito Federal ocupa a terceira posição entre os cinco Estados brasileiros que apresentam maiores números de adolescentes e jovens em restrição e privação de liberdade, considerando a faixa etária entre 12 e 18 anos e a população adolescente de cada Estado. São Paulo é a unidade da Federação com maior número de adolescentes em cumprimento de medida socioeducativa, com 9.614 do total de 23.066 adolescentes e jovens brasileiros em restrição e privação de liberdade (internação, internação provisória e semiliberdade), e que concentra o maior número de unidades, 136 unidades, o que representa $30 \%$ do total nacional (BRASIL, 2015b).

A medida socioeducativa de internação constitui-se em medida privativa de liberdade, sujeita aos princípios de brevidade, excepcionalidade e respeito à condição peculiar de pessoa em desenvolvimento (BRASIL, 1990). Isto é, a internação em unidades socioeducativas somente "deve ser aplicada quando for imprescindível, nos exatos limites da lei e pelo menor tempo possível" (BRASIL, 2006, p. 27). Na Resolução n. 119/2006 do Sinase, a finalidade da medida socioeducativa seria a responsabilização e 
a mais rápida inclusão social e, sobretudo, o pleno desenvolvimento pessoal e social do adolescente. Para alcançar estes objetivos é necessário conciliar a dupla natureza da medida socioeducativa: sua natureza sancionatória e sua natureza sociopedagógica (BRASIL, 2006).

\subsection{A DUPLA NATUREZA DA MEDIDA SOCIOEDUCATIVA DE INTERNAÇÃO: UM MISTO “DO CLAUSTRO, DA PRISÃO, DO COLÉGIO, DO REGIMENTO”}

Para Michel Foucault (2014), a data da abertura oficial de um reformatório na França, em janeiro de 1840, é a data em que se completa a formação do sistema carcerário. Um sistema que aglomera discursos e regulamentos que pregam a correção da delinquência ao mesmo tempo em que produzem mecanismos que a solidificam. Isto é, tem-se o início de uma nova forma de punir. Para o autor, o reformatório seria a forma disciplinar em seu estado mais intenso por concentrar todas as tecnologias coercitivas do comportamento: um misto "do claustro, da prisão, do colégio, do regimento" (FOUCAULT, 2014, p. 289). Mesmo sendo um tipo de instituição feita para não ser prisão, pelo contrário, uma instituição feita para evitá-la, o reformatório, para Foucault (2014), é uma prisão, uma “prisão falha”. Prisão, no sentido de que priva de liberdade ao mesmo tempo em que exerce a função do adestramento. $\mathrm{O}$ adestramento se traduz, neste caso, na normalização à força do indivíduo, por meio do uso de técnicas disciplinares.

Acompanhado do adestramento, existe uma observação constante do indivíduo, em que se registra o seu comportamento a cada instante do dia. Um dia no reformatório é preenchido por diversas atividades que possuem horários, obrigações e proibições (FOUCAULT, 2014). Erving Goffman (2013) também verificou esse controle do indivíduo por meio de atividades vigiadas dentro das instituições criadas pela sociedade com intuito de transformar os indivíduos. Ao refletir sobre as características das instituições totais, avaliou que o aspecto central destas instituições está na integração das esferas da vida que fora delas são dissociadas. Em um mesmo local, o indivíduo reside, trabalha e socializa. Todas estas esferas da vida são controladas por uma única autoridade que estabelece uma rotina de atividades. Em relação a elas, o autor observou que são realizadas diariamente, de forma obrigatória, em grupo de pares, sendo que cada uma tem um horário e duração determinados para que todas ocorram de forma sucessiva e organizada. Estas atividades são impostas por um sistema de regras e pelos funcionários 
da instituição e constituem um "plano racional único, supostamente elaborado para atender aos objetivos oficiais da instituição” (GOFFMAN, 2013, p. 18).

Um dia em uma unidade socioeducativa de internação no Distrito Federal também deve ser preenchido por atividades socioeducativas. A rotina de atividades de uma unidade de internação, ou a jornada pedagógica, como é chamada em algumas destas instituições, assemelha-se a esta vigilância ininterrupta descrita por Foucault (2014) e por Goffman (2013). O controle das atividades - atendimentos técnicos, escola, futebol, oficina ocupacional, curso profissionalizante, visitas, revistas íntimas manuais etc. - e do tempo é prática cotidiana nas unidades de atendimento socioeducativo de internação. A disciplina é cobrada e registrada em cada uma destas atividades. Diante disso, a disciplina na medida socioeducativa de internação não se encontra somente no eixo da segurança. Ao contrário disso, ela perpassa todos os seus sete eixos norteadores - 1 . Acompanhamento ao adolescente, à família e à comunidade; 2. Diversidade étnico-racial, gênero e orientação sexual; 3. Educação; 4. Esporte, cultura e lazer; 5. Saúde; 6. Profissionalização e trabalho; 7. Segurança (GDF, 2013a).

Compreende-se a disciplina não somente como o bom ou o mau comportamento, o cumprimento ou descumprimento de um procedimento, ela é mais do que isso. A disciplina, de acordo com Foucault (2014), é um tipo de poder composto por diversificados mecanismos - instrumentos, técnicas, procedimentos - que sujeitam o indivíduo a uma relação de dominação. Por meio desta relação de dominação, nascem indivíduos obedientes e úteis, os denominados "corpos dóceis" por Foucault (2014). Entretanto, o controle disciplinar não se faz somente por meio da simples imposição de gestos determinados, mas pela "melhor relação entre um gesto e a atitude global de um corpo" (FOUCAULT, 2014, p. 149). Isto é, ao adestrar, a disciplina retira e se apropria da melhor e da maior forma possível daquele indivíduo. Do modo que se exerce sobre os corpos, a disciplina consegue diminuir os inconvenientes de seu próprio poder, tornando seu exercício mais fácil e elevando seus efeitos ao máximo grau de intensidade e de extensão (FOUCAULT, 2014). 
De acordo com Foucault (2014, p. 215),

[...] enquanto os sistemas jurídicos qualificam os sujeitos de direito, segundo normas universais, as disciplinas caracterizam, classificam, especializam; distribuem ao longo de uma escala, repartem em torno de uma norma, hierarquizam os indivíduos em relação uns aos outros, e, levando ao limite, desqualificam e invalidam.

Neste movimento, o sistema carcerário substitui o infrator pelo delinquente. O que não significa que, por erro institucional, o encarceramento produza indivíduos piores. Ao contrário, a produção da delinquência faz parte de um mecanismo de "puniçãoreprodução" próprio do encarceramento. Por ser controlável, o delinquente é menos perigoso que o infrator. Além de ser extremamente útil para a ilegalidade da classe dominante, visto que sua ilegalidade passa a ser orientada para a prática de crimes mais leves (FOUCAULT, 2014).

A produção da delinquência passa por todos os mecanismos e estabelecimentos criados para evitar a prisão. Assim, contrariando o uso popular do "fora da lei", o delinquente nasce dentro da lei. A prisão conectada aos outros dispositivos "carcerários", desde conventos, reformatórios, hospitais a manicômios, exerce o poder de normalização. De acordo com Foucault (2014), fronteiras entre o encarceramento, os castigos judiciários e as instituições de disciplina são tênues e tendem a desaparecer. Esse desaparecimento implica constituição de um "continuum carcerário que difunde as técnicas penitenciárias até as disciplinas mais inocentes, ou seja, [...] uma rede carcerária sutil, graduada, com instituições compactas, mas também com procedimentos parcelados e difusos" (FOUCAULT, 2014, p. 293). Para Foucault (2014), existe relativa continuidade entre as instituições de encarceramento e seus mecanismos de vigilância e punição. De forma gradativa, saberes, técnicas, discursos, instituições e autoridades se organizam detalhadamente com a prática do poder de punir, do menor controle à maior condenação, sendo que a mesma instância que condena é a mesma que controla, transforma, corrige e melhora (FOUCAULT, 2014). 


\section{UMA NOVA FORMA DE PUNIR: A TRANSFORMAÇÃO DO INDIVÍDUO OU A RESSOCIALIZAÇÃO DO ADOLESCENTE INFRATOR}

A prisão é o espaço reservado para a delinquência produzida em encarceramentos anteriores, isto é, em todos aqueles estabelecimentos "dos quais fingíamos crer que se destinavam a evitar a prisão" (FOUCAULT, 2014, p. 296). A prisão, para Foucault (2014), seria a região mais sombria do aparelho de justiça, um lugar em que o poder de punir se exerce à luz do dia, com caráter terapêutico. Como uma máquina, os detentos se tornam engrenagens e produtos da prisão. As prisões fabricam delinquentes de forma direta e indireta. Os de forma direta são os que estão aprisionados em suas celas. Já os de forma indireta são os membros da família do preso que caem em situação de miséria. Por não deixar de fabricar delinquentes, as prisões não devolvem à sociedade indivíduos corrigidos como se espera, mas espalha delinquentes perigosos (FOUCAULT, 2014).

A instituição-prisão é anterior ao seu uso como pena. A transição do uso da prisão como pena se dá no fim do século XVIII e início do século XIX, quando o poder de punir sai das mãos do soberano e torna-se uma função geral da sociedade e a liberdade adquire status de bem universal, sendo considerada sua perda um valor comum (FOUCAULT, 2014). Dessa forma, o castigo sobre o corpo se transfere para a alma, visando à transformação do indivíduo. O corpo ferido desaparece e aparece o corpo do prisioneiro junto de sua alma "delinquente" (FOUCAULT, 2014). Assim, a prisão como pena não se resume à pura privação jurídica de liberdade, ela a excede.

Não foi somente a substituição dos suplícios por prisões fechadas e afastadas que ocorreu na passagem do século XIX, mas a substituição de uma forma de punir por outra (FOUCAULT, 2014). A prisão como uma punição legal nasce com a dupla função de privar de liberdade e transformar o indivíduo. Isto é, ela é a privação de liberdade preenchida por técnicas disciplinares, o chamado encarceramento. $\mathrm{O}$ encarceramento envolve, assim, a detenção mais um projeto técnico. É ao longo do seu acontecimento que suas "etapas, agravações temporárias, atenuações sucessivas" (FOUCAULT, 2014, p. 239) são determinadas. Não é o crime que determina o fim da pena, mas o comportamento do prisioneiro ao longo de seu cumprimento. 


\subsection{ENTRE SISTEMAS: O SOCIOEDUCATIVO E O PRISIONAL}

Foucault (2014) relata a mudança no objetivo do direito penal moderno, a saber, da punição para a readaptação dos delinquentes. Busca-se a transformação pedagógica dos indivíduos por um exercício contínuo. A punição visa não mais o pagamento do crime, mas à transformação do indivíduo culpado. Como ocorrem nas medidas socioeducativas, não é o ato infracional que deve determinar unicamente o tempo de cumprimento da medida, mas as avaliações do comportamento do adolescente ou do jovem infrator. É o julgamento, isto é, o diagnóstico dos detentores do poder penal de Foucault ou o parecer dos relatórios elaborados pelos servidores do sistema socioeducativo que determinam a continuidade, a progressão ou o encerramento da medida. A punição não se reduz à sentença, ao julgamento, ela se mantém em todo o

processo de execução da pena (FOUCAULT, 2014) ou, neste caso, ao longo do cumprimento da medida socioeducativa.

Os regimes disciplinares previstos no art. 71 da Lei n. 12.594/Sinase reproduzem leis; a determinação de sanções disciplinares dentro das unidades de internação imita os vereditos; o Conselho Disciplinar se assemelha à sessão de julgamento de um tribunal; o acompanhamento técnico pode se reduzir à vigilância policial. As semelhanças são tantas ao ponto de que as diferenças entre a prisão e a última instituição construída para evitá-la, como no caso das unidades socioeducativas de internação, devem ser imperceptíveis (FOUCAULT, 2014). Quando um jovem infrator, entre 18 e 20 anos de idade, sai do sistema socioeducativo e é apreendido no sistema prisional as diferenças entre um sistema e outro não devem ser sentidas.

\subsubsection{Uma triste coincidência}

Uma incrível semelhança nas proposições daqueles que buscavam melhores condições nas prisões foi constatada por Foucault (2014). Século após século, sete princípios fundamentais considerados como as sete máximas da boa "condição penitenciária" se repetiam. Outra semelhança não tão agradável é que estes princípios se traduzem em princípios, objetivos e diretrizes estabelecidos nos principais marcos regulatórios nacionais para a boa operacionalização das medidas socioeducativas. $\mathrm{O}$ primeiro destes princípios, o da correção, prioriza a transformação do indivíduo como 
objetivo da detenção penal. Este princípio se traduz no objetivo maior das medidas socioeducativas. Uma das dimensões básicas do atendimento socioeducativo prevista na Resolução n. 119/2006 do Sinase é que as ações socioeducativas devem influenciar a vida do adolescente, de forma a contribuir para a construção de sua identidade, fomentando o desenvolvimento de sua autonomia, solidariedade e de competências pessoais, cognitivas e produtivas (BRASIL, 2006).

O princípio da classificação, o segundo dos sete apontados por Foucault (2014), traz a importância da separação por idade, pela gravidade do crime cometido e pela fase de transformação e de técnica de correção que o detento se encontra. O art. 123 do Estatuto da Criança e do Adolescente (ECA) determina a obediência da rigorosa separação por idade, compleição física e gravidade do ato infracional pelas unidades de atendimento socioeducativo (BRASIL, 1990). O artigo é ainda reforçado nos Parâmetros Arquitetônicos para Unidades de Atendimento Socioeducativo, especificamente para as unidades de internação, previstos na Resolução n. 119/2006 do Sinase.

O terceiro princípio é o da modulação das penas, que argumenta acerca da possibilidade de interferência no tempo de cumprimento da pena a partir dos resultados avanços e retrocessos - obtidos durante o encarceramento. Este princípio é uma regra no caso da maioria das medidas socioeducativas, e não uma possibilidade. As medidas socioeducativas de prestação de serviços à comunidade, liberdade assistida, semiliberdade e internação não preveem prazo determinado. O tempo de cumprimento é definido por avaliações periódicas, conforme o art. 121, parágrafo $2^{\circ}$, do ECA. O princípio da modulação das penas se complementa com o princípio do controle técnico da detenção. Este último prevê o controle de pessoas especializadas e capazes de zelar pela boa formação dos detentos no regime da prisão. Ao considerar que as avaliações previstas no art. 121 do ECA possuem papel central na definição do tempo de cumprimento das medidas socioeducativas por adolescentes e jovens infratores, tem-se a magnitude do poder do parecer técnico elaborado por profissionais da área da Pedagogia, da Psicologia e do Serviço Social na execução das medidas socioeducativas.

Os princípios do trabalho como obrigação e direito e não como um agravamento da pena e o da educação penitenciária como dever do poder público se autoexplicam e, também, se assemelham às determinações do sistema socioeducativo. Ambos se traduzem em dois dos oito eixos estratégicos previstos nos parâmetros da ação socioeducativa, 
conforme a Resolução n. 119/2006 do Sinase: o Eixo Profissionalização/Trabalho/Previdência e o Eixo - Educação. Estes eixos organizam e orientam as ações das entidades e dos programas de atendimento socioeducativo. No caso do trabalho, compete às entidades e aos programas oferecer e garantir formação profissional com vistas à inclusão no mercado de trabalho. A respeito do Eixo Educação, são traçadas diversas ações que garantam com sucesso o acesso ou regresso e a permanência dos adolescentes e jovens na rede formal de ensino (BRASIL, 2006). Além da previsão em formato de eixos, trabalho e educação estão presentes de forma transversal em todas as normativas, dando embasamento a todo atendimento socioeducativo brasileiro. No ECA, fazem parte dos direitos do adolescente privado de liberdade previstos no art. 124 e, na Lei n. 12.594/2012 são áreas onde se devem ter obrigatoriamente ações (BRASIL, 1990, 2012).

Por fim, o sétimo princípio, das instituições anexas, coloca a necessidade de o detento ser assistido, em vez de vigiado, após o cumprimento da pena, até que esteja readaptado à vida após o encarceramento. O acompanhamento de egressos é uma preocupação do sistema socioeducativo encontrada em suas normativas, mas que ainda encontra-se distante da prática. A necessidade de um programa estruturado que atenda, de forma opcional, aos adolescentes e jovens após o cumprimento da medida socioeducativa, a fim de verificar sua situação em relação aos aspectos educacionais, profissionais, sociais e familiares, consta na Resolução n. 119/2006 do Sinase como uma das ações do Eixo - Suporte institucional e pedagógico, especificamente, indicada às entidades e/ou aos programas que executam a internação provisória e a medida socioeducativa de internação. Na Lei n. 12.594/2012 do Sinase, é um dos requisitos obrigatórios para a inscrição de programas de atendimento socioeducativo. Apesar da previsão legal e das tentativas de parcerias público-privadas por parte do governo, não existe, no Distrito Federal, um programa de atendimento a egressos do sistema socioeducativo.

\section{A RESSOCIALIZAÇÃO EM DISCUSSÃO}

Garland (2008) acredita que estamos vivendo um novo significado do encarceramento diante do declínio no ideal de reabilitação. A reabilitação dos indivíduos criminosos não justifica mais ideologicamente o sistema e nem ocupa posição de objetivo primordial de qualquer medida penal (GARLAND, 2008). O encarceramento, para o 
autor, serve atualmente para segregar tipos específicos de pessoas. Não somente as que cometeram crimes, mas as que foram rejeitadas pelas instituições da família, do trabalho e da previdência social. Essas pessoas são, em sua maioria, jovens, do sexo masculino, que têm sua exclusão econômica e social negligenciada por seu status criminal. A prisão torna-se uma solução para o problema da exclusão social e da marginalização econômica (GARLAND, 2008).

Para Wacquant (2011), a prisão funcionaria, de forma irônica, como política habitacional do Estado, isto é, a prisão serviria para os inúteis da nova economia. O encarceramento, neste caso, neutraliza e estoca fisicamente as frações excedentes da classe operária (WACQUANT, 2011). Dessa forma, para ambos os autores, as prisões continuam a funcionar, mas não mais como mecanismo de transformação, como discorreu Foucault (2014), e sim como instrumento de neutralização.

Não são os atos graves que mais encarceram no Brasil, apesar do alto índice de homicídios praticados no país. Deste modo, a política criminal brasileira também vem selecionando seus usuários não em função do crime cometido, mas em função da utilidade que possam ter ou não para o modelo político econômico. A essência excludente e concentradora de renda do neoliberalismo também empurra para as prisões a população pobre brasileira (NASCIMENTO, 2008). Nascimento (2008) considera que o que ainda separa o Brasil dos Estados Unidos em relação aos elevados índices de população carcerária é a idade de responsabilidade penal aos 18 anos e a ausência de prisão perpétua. No entanto, embora não seja contabilizado nos índices que medem a população carcerária brasileira, um universo de adolescentes e jovens infratores encontram-se encarcerados em unidades socioeducativas a fim de serem ressocializados.

O número de adolescentes cumprindo medidas socioeducativas privativas de liberdade cresceu 443,36\% entre 1996 e 2013 (GHRINGHLLI, 2015). O envolvimento de adolescentes com a criminalidade é tema recorrente de debates por parte das diferentes esferas de governo e da opinião pública no Brasil. Em meio a estes debates, ao longo dos últimos 20 anos, a defesa da redução da maioridade penal é acionada em alguns momentos como possível solução do problema. As propostas variam entre a simples redução da idade penal de 18 anos para 16 anos, o aumento do tempo de internação de três anos para até oito anos ou o julgamento do adolescente como adulto a depender do ato praticado (GHRINGHLLI, 2015). 
A inimputabilidade penal aos menores de 18 anos é um direito individual previsto no art. 228 da Constituição Federal de 1988 e garantido como cláusula pétrea. Entretanto, foi aprovada, em março de 2015, pela Comissão de Constituição, Justiça e Cidadania da Câmara Federal, que a redução da maioridade penal para 16 anos não fere a Constituição (MARIZ; SOUZA, 2015). Essa decisão viabilizou a tramitação da Proposta de Emenda Constitucional (PEC) n. 171/1993, que prevê a redução da maioridade penal de 18 anos para 16 anos nos casos de crimes hediondos. Em julho de 2015, esta PEC foi aprovada durante a madrugada pela Câmara dos Deputados, sendo que agora aguarda um segundo turno na Câmara e mais duas votações no Senado Federal (CARTA CAPITAL, 2015).

Rodrigo Ghringhelli (2015) avalia que existe uma tendência nos debates públicos de que o problema da criminalidade urbana juvenil deveria ser tratado como uma questão de reforma penal, no sentido do simples endurecimento das punições. Existe um disseminado consenso que afirma que adolescentes cometem atos infracionais por terem a certeza de que não serão punidos e presos como adultos. Primeiramente, se este argumento da impunidade fosse verdadeiro, o número de atos infracionais praticados representaria uma parcela significativa no índice de criminalidade brasileira, além de apresentar uma queda após os 18 anos (GHRINGHELLI, 2015). Por outra via, o argumento da ausência de punição também não se sustenta ao considerarmos o crescimento de $443,36 \%$ no número de adolescentes e jovens infratores submetidos a medidas socioeducativas com restrição de liberdade (internação, internação provisória e semiliberdade) em menos de duas décadas. Em números absolutos, passamos de um total de 4.245 adolescentes submetidos a medidas de restrição de liberdade em 1996 a um total de 23.066 adolescentes em 2013 (GHRINGHELLI, 2015). Isso demonstra o aumento da utilização, por parte do sistema de justiça juvenil, dos mecanismos de maior controle e punição previstos pelo Estatuto da Criança e do Adolescente (GHRINGHELLI, 2015).

O ideal de ressocialização está presente tanto na Lei de Execução Penal (Lei n. 7.210/1984) brasileira como no Sistema Nacional de Atendimento Socioeducativo (Sinase). Entretanto, Nascimento (2008) aponta que a função de reabilitação prevista nas penas está sendo substituída por um simples retributivismo a prazos cada vez mais longos. De acordo com Nascimento (2008), o atual cenário de questionamento do modelo penal-previdenciário também se passa no Brasil, sendo uma reprodução tardia do que ocorreu nos Estados Unidos e na Grã-Bretanha. Os elevados índices de reincidência contestam a proposta ressocializadora e a eficiência do aparelho penal como um todo, por 
não atenderem à crescente demanda. Assim, o modelo penal-previdenciário brasileiro passa a ser questionado e o novo senso comum do "nada funciona" se dissemina pelo país (NASCIMENTO, 2008).

Dessa forma, se há ou não um novo significado para o encarceramento, o próprio Garland (2008) ressalta que não é porque o ideal de reabilitação possa ter sido deixado para trás que o exame descrito por Foucault (2014), isto é, as avaliações, as classificações e a identificação dos fatores de risco e, por conseguinte, das possibilidades de tratamento dos indivíduos, foi extinto. Pelo contrário, “o poder punitivo ainda se combina com um enfoque psicossocial de diagnóstico e remediação" (GARLAND, 2008, p. 369). 


\section{CAPÍTULO 3 \\ OCORRÊNCIA DISCIPLINAR: SEUS PROCEDIMENTOS E REGISTROS}

Um procedimento pode estar ligado a um modo de agir ou de fazer algo. Dentro de uma unidade socioeducativa de internação, o termo procedimento está relacionado a condutas e comandos que devem ser obedecidos pelos internos e, também, descreve ações adotadas pela equipe de segurança. Andar de cabeça baixa, com as mãos para trás, em "fila indiana", aguardar atrás da linha amarela de um módulo e passar pela revista são exemplos de procedimentos realizados cotidianamente pelos adolescentes e jovens internados nas unidades socioeducativas do Distrito Federal. Vale ressaltar que a origem da utilização deste termo encontra-se no sistema prisional, conforme relata Debora Diniz (2015b).

Nas ocorrências disciplinares que ocorrem no contexto socioeducativo, as denominadas "situações-limite" no Projeto Político Pedagógico das Medidas Socioeducativas no Distrito Federal (PPP), diferentes procedimentos podem ser adotados, de forma individual ou mesmo coletiva. Os procedimentos vão de um registro da ocorrência no livro do plantão a encaminhamentos dos internos envolvidos para hospitais, delegacias, Instituto Médico Legal (IML) e outras unidades do sistema. Existe um regime disciplinar interno que descreve uma série de comportamentos que se caracterizam como ocorrências disciplinares dentro das unidades de internação. Desacato a servidor, brigas, ameaças, quebradeiras, fugas, agressões, incitação de tumulto enquadram-se em tipos de ocorrências disciplinares. Um desses comportamentos citados pode caracterizar uma ocorrência disciplinar de caráter leve, médio, grave ou mesmo gravíssimo. Para cada ocorrência, está prevista uma medida disciplinar - uma punição interna que se materializa em determinadas privações por certo número de dias decididos por um Conselho Disciplinar ${ }^{6}$.

Dessa forma, quando um interno se envolve em algum tipo de ocorrência disciplinar, ele é punido com alguma sanção definida em um colegiado institucional da unidade. Uma espécie de pequeno mecanismo penal dentro do sistema disciplinar da

\footnotetext{
${ }^{6}$ Após a aprovação do Regimento Interno das Unidades de Internação do Distrito Federal no ano de 2013, o Conselho Disciplinar passou a se chamar Comissão de Avaliação Disciplinar. Entretanto, apesar da alteração, o nome Conselho Disciplinar ainda consta nos atuais registros institucionais e continua sendo utilizado no cotidiano das unidades por servidores e internos.
} 
medida socioeducativa. Para além dessa sanção interna, mais de um procedimento pode ser adotado. Os internos que cometem alguma ocorrência disciplinar podem ainda ser encaminhados a delegacias para registro de boletim policial. Os adolescentes para as delegacias especializadas - Delegacia da Criança e do Adolescente (DCA) - e os jovens para as delegacias circunscricionais. Esse encaminhamento ocorre antes da realização do Conselho Disciplinar, logo após o cometimento da ocorrência disciplinar. A primeira escuta do adolescente ou do jovem infrator internado a respeito de sua possível responsabilidade sobre uma ocorrência disciplinar no contexto socioeducativo ocorre, por vezes, fora da unidade, em uma delegacia.

Esse procedimento institucional pode acarretar ingresso do jovem infrator no sistema prisional pela mão do sistema socioeducativo. Uma ocorrência disciplinar no sistema socioeducativo pode se tornar um crime ou uma contravenção penal, isto é, uma infração penal de maior ou menor potencial ofensivo.

\title{
1 A OCORRÊNCIA
}

Em um relato padrão de uma ocorrência disciplinar, horário, data, local, nomes, situação e providências tomadas são registrados de forma sucinta por um dos servidores da equipe de segurança envolvido na ocorrência. É dessa forma que ela é lida nos espaços institucionais, como é contada pela primeira vez para o Poder Judiciário e deste modo que fica arquivada no dossiê do jovem infrator:

\begin{abstract}
Por volta das $17 \mathrm{~h}$, do dia dois de janeiro do ano em curso, o módulo 05 , durante o fechamento da ala verificou-se que no quarto 03 lado "B", havia um colchão em pedaços. Os agentes questionaram o dano aos adolescentes do quarto. Em seguida o socioeducando assumiu a autoria do fato, alegando tê-lo destruído em virtude da necessidade de um novo. Diante dos fatos o interno em questão foi encaminhado à $27^{\mathrm{a}} \mathrm{DP}$ para registro de ocorrência n. ${ }^{\circ}$ 0000/2014, onde ficou preso em flagrante delito (Ocorrência disciplinar) ${ }^{7}$.
\end{abstract}

A hora não é exata. Sempre é por volta de algum horário. Por vezes, alguma atividade na rotina programada da unidade de internação indica o tempo do ocorrido.

\footnotetext{
${ }^{7}$ A data da ocorrência foi alterada para o primeiro dia útil do ano de 2015 (data de referência do efetivo neste estudo). Além disso, os nomes dos jovens e atendentes de reintegração socioeducativa descritos na ocorrência e o número do registro de ocorrência policial foram subtraídos.
} 
Após o jantar, na abertura dos alojamentos, no banho de sol, durante a revista ou no deslocamento para a escola orientam o passar do tempo nas unidades de internação. Os relógios são escassos e de propriedade particular dos servidores. Sobre os dias que ocorrem, em geral, os fins de semana são mais preservados. Sábado e domingo é dia de ver a família e receber a "cobal" da semana ${ }^{8}$. Assim, é entre as segundas e as sextas-feiras que as faltas disciplinares mais ocorrem. Nas três unidades pesquisadas, considerando apenas aquelas ocorrências disciplinares de 2014 com o dia da semana identificado, $85 \%$ ocorreram entre segunda e sexta-feira ${ }^{9}$.

O módulo é o lugar mais frequente. Outros espaços dentro da instituição também são passíveis para faltas disciplinares: escola, oficinas, campo de futebol ou durante um deslocamento. No entanto, o módulo, por ser o lugar em que os jovens passam mais tempo durante o dia de internação, é o principal deles. O maior período de tempo pode tornar o módulo o lugar mais propício de uma unidade para ocorrências disciplinares, mas o atual quadro de superlotação nas unidades socioeducativas do Distrito Federal acrescenta outros elementos ao fator tempo. Existe uma concepção arquitetônica estabelecida na Resolução n. 119/2006 do Sinase (BRASIL, 2006). Nessa concepção, os espaços residenciais - denominados de módulos nas unidades - devem ter um limite máximo de 15 internos.

Um módulo na Unidade de Internação do Recanto das Emas (Unire) é dividido ao meio, em dois lados, ou, como também é chamado, em duas alas. Cada lado possui quatro alojamentos, conhecidos também por quartos, barracos ou celas. Cada alojamento possui duas camas. Cama não é um bom substantivo para descrever o objeto encontrado nos alojamentos. Os internos chamam de "jega" as duas superfícies retangulares de cimento presentes nos alojamentos. O estreito espaço no chão entre as duas superfícies retangulares de cimento é destinado para um colchão. Dessa forma, são três jovens por alojamento, 12 jovens por lado e 24 jovens por módulo. Contudo, em tempos de superlotação, cada módulo chega a abrigar 40 jovens, 20 por lado, cinco por alojamento.

\footnotetext{
${ }^{8}$ Cobal é a sigla para Companhia Brasileira de Alimentos. Nas unidades de internação, o termo cobal é utilizado para ser referir a alimentos, materiais de higiene e roupas que são autorizadas a entrar nas unidades. A cobal é de responsabilidade das famílias e há um dia específico para ser entregue e a quantidade de cada item.

${ }^{9}$ Das 397 ocorrências disciplinares que ocorreram no ano de 2014 nas unidades socioeducativas que possuem jovens em seus efetivos (Unire, Uniss e Uibra), em 381 foi possível identificar os dias da semana, sendo que $324(85 \%)$ ocorreram entre segunda e sexta-feira e 57 (15\%) ocorreram nos finais de semana.
} 
São condições que podem tornar a convivência diária e obrigatória bem mais difícil. A ausência de habitabilidade, condições de higiene, privacidade e conforto são fatores que fazem parte da rotina e podem culminar em variadas ocorrências disciplinares.

Ameaça, ocultação, porte e uso de substância entorpecente, dano ao patrimônio, agressão física, desacato, incitação ao tumulto, fuga, evasão, atos de indisciplina, autolesão, agressão verbal, porte de objeto proibido e a tentativa de qualquer uma dessas ações mencionadas são possíveis ocorrências disciplinares dentro das unidades de internação (GDF, 2013b). Dentre essas situações, algumas são fáceis de nomear e logo classificar, como uma agressão física ou um dano ao patrimônio. Outras são mais complicadas e podem ser difíceis de identificar. Por exemplo, um ato de indisciplina, uma ameaça, uma agressão verbal ou um desacato variam não somente pela subjetividade envolvida na percepção, mas pelas determinações das relações de hierarquia, poder e disciplina estabelecidas dentro de uma unidade de internação.

Além da dificuldade que pode envolver o momento de tipificar uma destas ações, em uma ocorrência disciplinar é preciso ainda identificar o responsável, o(s) culpado(s). A identificação, geralmente, é feita pelo servidor que estava presente no momento do ato de indisciplina. A confissão da responsabilidade pela ocorrência só compete ao autor. A delação em uma unidade de internação não acarreta prêmio, mas retaliações. Aquele que delata o outro dentro de uma unidade de internação é o vulgo "caguete" ou o "x9" que merece punição por parte de seus pares, que se manifesta desde agressão física até o isolamento.

Todos esses relatos - hora, data, local, situação e o(s) nome(s) do(s) culpado(s) são feitos por servidores, em específico, os atendentes de reintegração socioeducativo ATRS que presenciaram o ocorrido. Cabe ressaltar que os atendentes de reintegração socioeducativo também são chamados de agentes, educadores ou socioeducadores ${ }^{10}$. Apesar da diferença entre os nomes e nos possíveis significados de cada um, são todos utilizados dentro do sistema socioeducativo, a depender do contexto e de quem os utiliza. O registro de um servidor público tem presunção de veracidade. O que eles perceberam, o

\footnotetext{
${ }^{10}$ Após a criação da Carreira Socioeducativa, em junho de 2014, por meio da Lei n. 5.351/2014, os nomes dos cargos foram alterados. Antes desta lei, tanto o cargo de Especialista quanto o de Atendente de Reintegração eram vinculados à carreira da Assistência Social e, assim, se chamavam Especialista em Assistência Social e Atendente de Reintegração Social. A lei também trouxe a mudança no nível de escolarização exigido para ingresso no cargo de Atendente de Reintegração Socioeducativo, do nível médio para o nível superior.
} 
que avaliaram sobre o ocorrido e quem são os possíveis culpados até que se prove o contrário é registrado. O registro é só uma das responsabilidades da equipe de agentes, pois eles também fazem todos os procedimentos devidos: contenção, encaminhamentos e ajudam a definir a sanção.

O primeiro passo é a contenção. A contenção pode ser realizada com ou sem o uso de algemas, apesar da Súmula Vinculante n. 11 do Supremo Tribunal Federal (STF) que regulamenta e restringe o uso de algemas a casos excepcionais. Contidos, os jovens são encaminhados para o módulo disciplinar. Em cada unidade socioeducativa no Distrito Federal existe um módulo, um pavilhão, uma ala ou alguns alojamentos específicos para o cumprimento de medida disciplinar. Na Unidade de Internação do Recanto das Emas, o módulo disciplinar se chama módulo 07. A estrutura física não se difere dos demais módulos, as diferenças estão nas regras de convivência. Nesse espaço, o cigarro e a televisão são proibidos e a única visita autorizada é a da responsável ${ }^{11}$. Os horários de banho de sol são reduzidos e as atividades externas limitadas à escola.

Contudo, apesar de o módulo disciplinar ser o espaço destinado ao castigo, nele não estão apenas aqueles que cometeram uma ocorrência disciplinar. $\mathrm{O}$ castigo serve também para algum jovem com comportamento considerado difícil, isto é, aqueles jovens que questionam os procedimentos, provocam os demais, solicitam coisas sucessivamente, exigem explicações para tudo, mesmo que não tenha se envolvido em ocorrências disciplinares. E serve, ainda, para os casos em que a convivência protetora não foi suficiente. Existe no Sinase a previsão da convivência protetora em situações em que isso seja necessário. O módulo de convivência protetora é destinado para aqueles jovens que precisam ser resguardados da convivência coletiva por terem sua integridade física e/ou psicológica ameaçadas (BRASIL, 2006). Os adolescentes e jovens que se encontram nesse módulo acabam sendo chamados de PIF pelos servidores das unidades. Para os adolescentes e jovens em situação de proteção à integridade física (PIF) que não tiveram boa adaptação, nem mesmo no módulo de convivência protetora, o destino é o isolamento no módulo disciplinar ou a transferência de unidade.

O encaminhamento para o módulo disciplinar após o envolvimento em uma ocorrência disciplinar pode ser seguido ou antecedido pelo encaminhamento para uma

\footnotetext{
${ }^{11} \mathrm{O}$ uso do gênero feminino justifica-se porque são as mães, em praticamente todos os casos, as que se responsabilizam pelo acompanhamento dos adolescentes e jovens em cumprimento de medida socioeducativa.
} 
delegacia. O encaminhamento para delegacia não está prescrito no Sinase, mas se tornou uma prática socioeducativa no Distrito Federal. Das 397 ocorrências disciplinares que ocorreram no ano de 2014 nas unidades socioeducativas de internação com maiores em seus efetivos - Unidade de Internação do Recanto das Emas (Unire), Unidade de Internação de Saída Sistemática (Uniss) e Unidade de Internação de Brazlândia (Uibra) -, 129 também se tornaram ocorrências policiais. A maioria delas por agressões físicas a adolescentes e mútuas, dano ao patrimônio e porte de substância entorpecente.

O atendente de reintegração socioeducativo (ATRS), com o direito garantido a qualquer outra pessoa, decreta prisão em flagrante delito dentro da unidade e encaminha o jovem interno para alguma delegacia para registro de boletim policial. Na delegacia, o agente, na qualidade de servidor público, tem presunção de veracidade. O jovem pode ser réu confesso, não se pronunciar ou não querer registrar - principalmente, nos casos em que a ocorrência envolve um de seus pares. Após o registro de boletim policial, o jovem pode ser preso em flagrante ou liberado para retornar para a unidade socioeducativa. Preso, o destino, na maioria das vezes, é o Centro de Detenção Provisória (CDP). Liberado, o destino é o módulo disciplinar da unidade. No entanto, preso ou liberado, um processo criminal pode ser instaurado. E estar liberado não significa isenção de punição.

No retorno para a unidade, o Conselho Disciplinar é instaurado em no máximo cinco dias úteis para definir sua medida disciplinar, sua sanção. O Conselho Disciplinar é uma espécie de colegiado interno formado por servidores do corpo técnico e da segurança da instituição que definem, a partir de um regime disciplinar institucional, a medida disciplinar que um jovem deve cumprir nos casos do envolvimento em uma ocorrência disciplinar. O regime disciplinar está previsto no Sinase tanto em forma de resolução como na forma de lei federal. Nesse regime, constam condutas consideradas inapropriadas e que são proibidas dentro de uma unidade de internação. Não existe um padrão, um único regime para as unidades de internação, mesmo aquelas de uma mesma unidade federativa.

Cada ocorrência disciplinar, como mencionado, é classificada como uma falta leve, média, grave ou gravíssima. Para cada falta existe um número mínimo e um número máximo de dias que o interno deve permanecer no módulo disciplinar em cumprimento de sanção. Em sua concepção, o Conselho Disciplinar não deveria ser resumido ao cumprimento de dias no castigo, ou seja, a uma punição. O Conselho Disciplinar deveria 
ter um caráter socioeducativo, educacional, de modo que medidas alternativas ao módulo disciplinar fossem também estabelecidas. Entretanto, medidas alternativas são algo ainda raro de acontecer dentro das unidades socioeducativas.

Assistentes sociais, pedagogas, psicólogas, atendentes de reintegração socioeducativo e demais servidores da equipe de segurança se reúnem em volta de uma mesa para interrogar, acusar, defender e definir uma sanção disciplinar, após uma série de perguntas e da negociação de dias ${ }^{12}$. Assim como em uma sessão de julgamento, o acusado, o jovem em questão, senta na ponta da mesa, de um lado a equipe técnica e do outro o chefe de módulo e algum atendente de reintegração socioeducativo que presenciou o ato de indisciplina. A dúvida em relação à autoria, as motivações como justificativas e a compreensão das dificuldades que a situação de privação de liberdade acarreta são possíveis argumentos de defesa. Os pequenos atos de indisciplina anteriores, o dever de prevenir atos futuros mais graves, a necessidade de punir para educar e a consideração do jovem como um infrator nato são compreensões que permeiam os recorrentes argumentos daqueles que acusam. No meio, o gerente de segurança como aquele que comunica ao réu a decisão final.

Todos sentados, é feita a leitura da ocorrência, para logo em seguida iniciar o interrogatório. Após a leitura, o jovem diz se concorda ou não com os fatos narrados. Sua fala se tornará um novo registro chamado de Termo de Declaração. Um Termo de Declaração de um Conselho Disciplinar segue o padrão da escrita recorrente na descrição dos fatos processuais. A preposição "que" está presente do começo ao fim:

\begin{abstract}
No dia dois do mês de janeiro do ano de dois mil e quinze, neste Distrito Federal, na sede da Unidade de Internação do Recanto das Emas - UNIRE esteve presente o adolescente que após escutar a leitura da ocorrência $\mathrm{n}^{\circ}$. 000/2014, prestou a seguinte versão dos fatos: QUE não concorda com o relato da ocorrência; QUE afirma não ter agredido o outro jovem; QUE afirma não ter nada a ver com as agressões; QUE ao ser perguntado o motivo das acusações, o declarante afirmou que não sabe; QUE afirma não ter tido nenhum desentendimento com o outro jovem, apenas havia brincadeiras de "meia-hora"; QUE afirma saber que o outro jovem tem alguns desentendimentos no módulo; QUE afirma ter conhecido o outro jovem no CESAMI, mas não houve convívio, nem conflito; QUE confirma saber da agressão contra o outro jovem, mas não indica ninguém, apenas sustenta que não o agrediu; QUE nada mais foi dito ou perguntado e, em consequência é lavrado o presente termo, depois de lido e considerado em conformidade, segue
\end{abstract}

\footnotetext{
${ }^{12} \mathrm{O}$ uso do gênero feminino para se referir aos profissionais do corpo técnico se explica pelo elevado número de mulheres que ocupam estes cargos.
} 
devidamente assinado (Termo de Declaração de jovem em relação a prática de uma ocorrência disciplinar $)^{13}$.

Assim, o Termo de Declaração torna-se a confissão do interno. É o registro da sua fala durante o interrogatório. O interno é perguntado acerca dos fatos e presta a sua versão. Primeiramente, ele deve dizer se concorda ou discorda do relato da ocorrência disciplinar. Depois, responde às perguntas e faz suas afirmações. O interno torna-se o declarante. Se nada mais for dito ou perguntado, o presente termo é assinado, depois de lido em voz alta.

Não só perguntas são feitas, afirmações e julgamentos morais de sua conduta também fazem parte deste momento. Resta ao jovem assumir a culpa ou negar esperando que acreditem. Caso não tenha sido o responsável pela ocorrência disciplinar, ele é lembrado que tem sido muito questionador nos últimos tempos e que isso incita os outros jovens a causar tumulto no módulo. E mesmo que sua inocência seja provada, é possível que o espaço seja aproveitado para lembrá-lo de que ele está sendo observado constantemente e que qualquer falha pode comprometer seu processo socioeducativo.

A partir dos fatos narrados na ocorrência escrita, da escuta de possíveis agentes que estavam no dia do ocorrido e do interrogatório do jovem, é decidido por todos os membros do Conselho seu tempo de medida disciplinar. O tempo da sanção é contado em dias. Os dias em que o jovem permaneceu no módulo disciplinar aguardando a realização do Conselho entram nesta contagem. Caso o jovem seja inocentado, o tempo no módulo disciplinar se perde nos dias de cumprimento da medida socioeducativa. Atenuantes e agravantes também fazem parte do julgamento e influenciam no número de dias. Se um jovem está pela primeira vez envolvido em uma ocorrência disciplinar, se ele é elogiado na escola, se é considerado cordial pelos agentes, seus dias podem ser reduzidos. Se, pelo contrário, ele é frequente na sala do Conselho Disciplinar, considerado rebelde e questionador, seus dias de sanção disciplinar podem chegar ao máximo possível.

O fechamento desse processo culmina em novo registro, um relatório chamado: Relatório da Comissão de Avaliação ou Relatório de Conselho Disciplinar. O nome pode variar, a depender da unidade. Os Conselhos Disciplinares são conduzidos por membros

\footnotetext{
${ }^{13}$ A data e o número da ocorrência foram alterados, no caso da data, para o primeiro dia útil do ano de 2015 (data de referência do efetivo neste estudo). Além disso, os nomes dos jovens descritos na ocorrência foram subtraídos.
} 
da Gerência de Segurança e ocorrem em salas, espaços desta Gerência. Já os Relatórios são escritos por membros da Gerência Socioeducativa. Essa Gerência é responsável pelas demandas que envolvem o corpo técnico da unidade. Um de seus membros acompanha o técnico de referência no Conselho Disciplinar e fica responsável pela elaboração desse relatório.

A primeira parte do relatório consiste na Identificação. Primeiramente, o número da ocorrência, data, módulo e o nome ou os nomes dos internos envolvidos. Depois, são identificados os participantes do Conselho Disciplinar. Os participantes são, via de regra, cinco: um representante da Gerência de Segurança e outro da Gerência Socioeducativa, um técnico de referência, o chefe do módulo e a agente escrivã. Apesar da obrigatoriedade da presença do técnico de referência, conforme art. 71 do Sinase, esta presença nem sempre é cumprida, o que pode resultar na anulação do Conselho Disciplinar.

A despeito do caráter obrigatório da presença de um membro do corpo técnico, as diferenças e semelhanças entre seu papel e o dos membros do corpo da segurança não são definidas. Considera-se que a equipe de referência deve trazer elementos como o histórico de vida, a trajetória do jovem no processo socioeducativo e demais fatores que contribuam para a sua avaliação na ocorrência em questão. No entanto, o desenvolvimento deste papel não constitui uma regra e pode endossar o discurso da punição como meio para educação. Após todos identificados, é feito o enquadramento normativo da ocorrência, ou seja, um resumo descrevendo em poucas palavras: o ato, o tipo da ocorrência - gravíssima, grave, média, leve, sem especificação -, os dias possíveis de medida disciplinar e a característica da ocorrência - individual ou coletiva.

A segunda parte é a de Discussão e Orientação. Nela, há variações em relação ao que é dito, a depender de quem escreve. Em alguns relatórios, constam pontos atenuantes do(s) interno(s) envolvido(s) e pontos agravantes. Comporta-se de forma adequada durante a realização do Conselho, ser assíduo e ter bom aproveitamento nas atividades pedagógicas e ter primariedade em falta disciplinar são exemplos de pontos atenuantes. Ter sido o organizador ou promotor da falta disciplinar e/ou não estar envolvido em sua primeira ocorrência, isto é, não ser réu primário (ter envolvimentos recorrentes em ocorrências disciplinares), tornam-se pontos agravantes na decisão da medida disciplinar. Isto é, na decisão do tempo máximo, número de dias. 
Detalhados os atenuantes e agravantes, é apresentada a versão do interno sobre a ocorrência da qual está sendo acusado. A versão do interno é a garantia do contraditório no relatório. A descrição de sua fala é a partir da leitura da ocorrência. Devem constar o que ele afirma que ocorreu naquele dia e as respostas às perguntas dos membros do Conselho. Finalizada a descrição da fala, encerrada as perguntas, compete à comissão orientar o interno sobre o seu comportamento. As orientações descritas dizem respeito às consequências dos atos cometidos e como isso se reflete negativamente no cumprimento da medida socioeducativa. Técnicos e agentes lembram ainda como o comportamento do interno é avaliado diariamente e que todas as suas atitudes são informadas ao Poder Judiciário.

A terceira e última parte é a Deliberação do Conselho, ou seja, a descrição do tempo de medida disciplinar e de onde será cumprida: no módulo disciplinar ou no módulo de origem. Os representantes das Gerências assinam e o documento está pronto para ser enviado ao Poder Judiciário. Esse relatório é finalizado dias depois da realização do Conselho e dos registros da ocorrência disciplinar e do boletim policial. Assim estes primeiros registros com a ausência de comprovações já tiveram ciência por parte do Poder Judiciário. Em alguns casos, até mesmo o cumprimento de medida disciplinar pode ter ocorrido.

Estes dois documentos - Termo de Declaração e o Relatório de Conselho Disciplinar - passam a compor a primeira ocorrência descrita. Ambos são enviados para o Poder Judiciário e arquivados no dossiê dos jovens. Como o envio ocorre dias depois daquele primeiro registro da ocorrência, conforme mencionado, nos casos de absolvição no Conselho o jovem pode ainda ser prejudicado. Se alguma decisão a respeito de benefício está prestes a ser tomada e o primeiro registro da ocorrência disciplinar chega à Vara de Execução Medidas Socioeducativas (VEMSE), o jovem pode ter seu benefício negado, mesmo que posteriormente sua inocência seja comprovada. Além dos dias que ele passou no módulo disciplinar aguardando a realização do Conselho que não voltam mais.

E aqueles jovens que não voltam da Delegacia? Aqueles que "descem"? Estes vão, na maioria dos casos, para o Centro de Detenção Provisória (CDP). O tempo no CDP é bastante variável, pode ir de poucos dias a meses. O crime quase sempre é o mesmo: dano ao patrimônio público, art. 163 do Código Penal. Dos 33 desligamentos 
para o sistema prisional no ano de 2014, 22 (67\%) foram pelo crime de dano ao patrimônio público. Os demais se dividiram entre os crimes de tentativa de homicídio, em três casos, e de tráfico de drogas, em um caso. Em cinco casos, os jovens foram desligados em virtude do cumprimento de mandados de prisão e nos outros dois casos não foi possível identificar a razão do desligamento.

O que determina o tempo de apreensão no sistema penitenciário não é nítido. $\mathrm{O}$ pagamento da fiança pode ser uma dessas variáveis. A maioria das fianças arbitradas encontradas nos casos de dano ao patrimônio foi de um salário mínimo, mas mesmo sendo considerada de baixo valor monetário, poucos foram os que conseguiram pagá-la. Assim, após quatro dias ou quatro meses no sistema prisional, o jovem retorna para o sistema socioeducativo. Se o tempo apreendido for de poucos dias, é provável ainda que retorne para o módulo 07, onde irá aguardar a realização de seu Conselho Disciplinar e uma nova punição será definida. Se for de meses, o retorno é para algum módulo de convivência, no que estava anteriormente ou mesmo em um novo módulo.

A medida socioeducativa continua. O jovem passa a viver dentro de uma unidade socioeducativa de internação pensando como pode ser seu futuro dentro de uma unidade prisional. O jovem responde simultaneamente a um processo infracional e a um processo criminal. De dentro da unidade de internação, ele é encaminhado para audiências e pode ter a qualquer momento um mandado de prisão decretado. A maioridade dentro de uma unidade socioeducativa se torna um limbo para o sistema prisional. 


\section{CAPÍTULO 4 \\ DAS UNIDADES, JOVENS E OCORRÊNCIAS DO SISTEMA SOCIOEDUCATIVO ATÉ AS DELEGACIAS E AS PRISÕES DO SISTEMA PRISIONAL}

\section{O SOCIOEDUCATIVO}

\subsection{AS UNIDADES SOCIOEDUCATIVAS}

A medida socioeducativa de internação não possui prazo determinado, entretanto, não pode exceder três anos, sendo ainda prevista a liberação compulsória caso o jovem infrator complete 21 anos de idade. De acordo com o Projeto Político Pedagógico da Medida Socioeducativa de Internação elaborado pela Secretaria de Estado de Políticas para Crianças, Adolescentes e Juventude (Secriança), a maior parte de adolescentes e

jovens infratores em cumprimento de medida socioeducativa de internação no Distrito Federal possui entre 18 e 21 anos de idade (GDF, 2013a).

O Distrito Federal possui formalmente um total de seis unidades de internação, sendo que quatro foram inauguradas recentemente, nos anos de 2013 e 2014. São elas: Unire (Unidade de Internação do Recanto das Emas, antigo Ciago), Uip (Unidade de Internação de Planaltina, antigo Ciap), Uiss (Unidade de Internação de São Sebastião), UISM (Unidade de Internação de Santa Maria), Uniss (Unidade de Internação de Saída Sistemática) e Uai (Unidade de Atendimento Inicial), unidade em que se realiza um primeiro atendimento ao adolescente apreendido em flagrante até que ele seja encaminhado para a medida determinada (GDF, 2014a). A sétima unidade é a Uibra (Unidade de Internação de Brazlândia), que possui estrutura física e direção nomeada, mas funciona em caráter provisório dentro da unidade de São Sebastião.

Das sete unidades de internação de adolescentes e jovens infratores no Distrito Federal, três apresentam formalmente em seus efetivos jovens infratores, entre 18 e 20 anos de idade, em cumprimento de medida socioeducativa de internação estrita. São elas: Unire, Uniss e Uibra. A Unidade de Internação do Recanto das Emas (Unire) é, atualmente, a unidade destinada exclusivamente para jovens infratores entre 18 e 20 anos de idade em cumprimento de medida socioeducativa. A Unire está localizada na cidade do Recanto das Emas, uma das 31 RAs do Distrito Federal, e funciona desde julho de 2006. Ao longo de quatro anos, a Unire exerceu suas atividades por meio de convênios e 
contratos entre Governo do Distrito Federal (GDF) e entidades privadas (GDF, 2014b). Em julho de 2010, o GDF assumiu integralmente a gestão da Unidade do Recanto das Emas e, no mês de março de 2014, a unidade passou a atender exclusivamente jovens do sexo masculino entre 18 e 21 anos incompletos de idade.

A Uniss foi inaugurada em dezembro de 2013 e também está localizada na RA do Recanto das Emas. Essa unidade atende aos adolescentes e jovens que, em cumprimento da medida socioeducativa de internação, estão em usufruto do benefício de saídas sistemáticas. A unidade tem capacidade máxima para 80 adolescentes e jovens infratores e estrutura-se em quatro Casas de Convivência (GDF, 2014a). A gestão do sistema socioeducativo no Distrito Federal, com base no trabalho socioeducativo por fases proposto no Sinase, considera o usufruto do benefício de saídas como etapa conclusiva da medida socioeducativa de internação, isto é, os adolescentes e os jovens infratores que se encontram em usufruto de saídas sistemáticas estariam finalizando sua medida socioeducativa de internação, prestes a serem liberados.

Sobre a Unidade de Internação de Brazlândia (Uibra), seu funcionamento ocorre de forma temporária na Unidade de Internação de São Sebastião (Uiss) desde o mês de agosto de 2014, sendo que os primeiros jovens chegaram no mês seguinte. A previsão da Secretaria de Estado de Políticas para Crianças, Adolescentes e Juventude (Secriança) para inauguração da Uibra era para o primeiro semestre de 2014, no mês de junho. Existe uma estrutura física praticamente pronta na cidade de Brazlândia e foram realizadas a nomeação da equipe de direção e a contratação de funcionários temporários, contudo, até este momento, a unidade não foi inaugurada. A Uibra, assim como a Unire, é destinada exclusivamente para jovens infratores, de 18 a 20 anos de idade, em cumprimento de medida socioeducativa de internação. Os jovens que foram acautelados na Uibra estão alojados em três módulos na Unidade de São Sebastião (Uiss). Além de o espaço físico ser cedido, a equipe de servidores que realiza o atendimento aos jovens infratores também faz parte do corpo técnico da Uiss. 


\subsection{OS JOVENS INFRATORES}

No dia 2 de janeiro de 2015, havia 308 jovens do sexo masculino, entre 18 e 20 anos de idade, em cumprimento de medida socioeducativa de internação no Distrito Federal. Destes 308 jovens, 215 se encontravam na Unire, 55 na Uibra e 38 na Uniss. Ao considerar a capacidade máxima de cada unidade de acordo com a Coordenação de Internação da Secretaria da Criança (Secriança), verifica-se que a Unire apresentava um quadro de superlotação, considerando que sua capacidade máxima é de 144 internos, ao contrário da Uniss, que respeitava sua capacidade máxima de 80 internos, com o efetivo de 58 internos, entre adolescentes e jovens (GDF, 2014a).

A respeito dos jovens da Uibra que se encontram de forma temporária na Uiss, não é possível definir um quadro exato de vagas e lotação. No entanto, ao considerar que a capacidade máxima de cada módulo da unidade é de 20 internos, e analisando o efetivo por módulo, avalia-se que, apesar de os três módulos estarem cheios, os alojamentos estão divididos por apenas dois jovens, o que garante condições mínimas de habitabilidade e respeita o número total de vagas, no caso, 60. O Gráfico 1 apresenta a distribuição do número de jovens em cumprimento de medida socioeducativa de internação e a capacidade de lotação de cada unidade.

Gráfico 1 - Distribuição do total de jovens internados e a capacidade de lotação

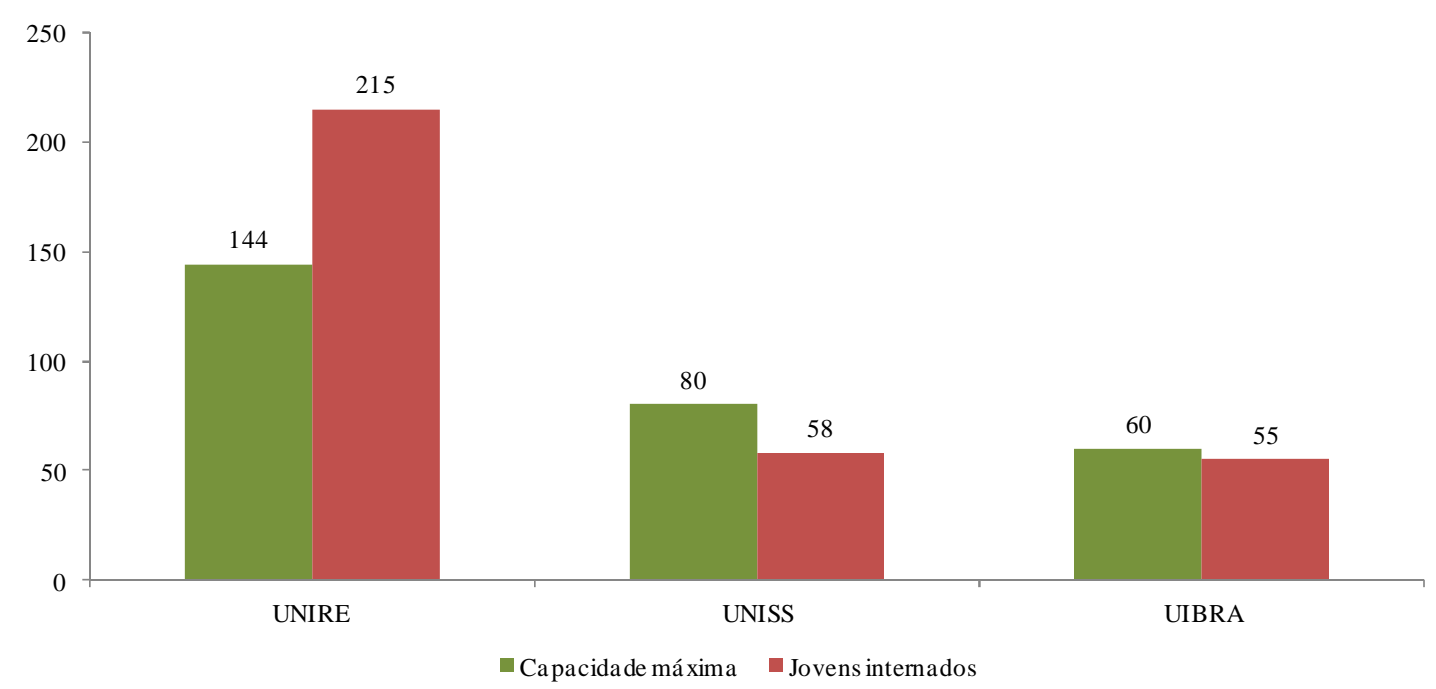

Fonte: Efetivos disponibilizados pelas unidades - Unire, Uibra e Uniss - e capacidade máxima disponível no site da Secretaria de Estado de Políticas para Crianças, Adolescentes e Juventude do Distrito Federal. 
Observa-se que a Unire apresenta um quadro de superlotação, visto que há um excedente de $50 \%$ de internos. As demais unidades conseguiram respeitar o limite máximo de internações.

\subsection{AS OCORRÊNCIAS DISCIPLINARES}

Dos 308 jovens que se encontravam em cumprimento de medida socioeducativa de internação no dia 2 de janeiro de 2015, cerca de 30\%, isto é, 94 jovens, o que equivale a praticamente um a cada três, havia se envolvido em ocorrências disciplinares ao longo do ano de 2014, conforme mostra a Tabela 1, que traz a distribuição do número de jovens infratores por unidade. Na Unire, $29 \%$ do total de jovens internados havia cometido alguma ocorrência disciplinar em 2014. Já na Uibra, do total de 55 jovens internados, 21 (38\%) apresentavam ocorrências disciplinares em 2014 em seu cadastro.

Tabela 1 - Distribuição de jovens envolvidos em ocorrências em 2014 em relação ao total de
jovens em cada unidade

\begin{tabular}{lc|cc}
\hline Unidade & Jovens internados & $\begin{array}{l}\text { Jovens envolvidos em } \\
\text { ocorrências em 2014 }\end{array}$ & $\%$ \\
\hline UNIRE & 215 & 62 & $29 \%$ \\
UIBRA & 55 & 21 & $38 \%$ \\
UNISS & 38 & 11 & $29 \%$ \\
\hline Total & 308 & 94 & $31 \%$ \\
\hline
\end{tabular}

Fonte: Cadin da Uniss, Uibra e Unire. Elaborada pela autora.

A Tabela 2 apresenta a proporção de jovens internados e envolvidos em ocorrências em 2014, em relação ao total de jovens internados no dia 2 de janeiro de 2015, e que se envolveram em ocorrências disciplinares. Do total de jovens internados, a Unire contribui com $70 \%$ do total, sendo que o menor número de jovens internados encontra-se na Uniss (12\%). 
Tabela 2 - Proporção de jovens internados e jovens envolvidos em ocorrências em $2014 \mathrm{em}$ relação ao efetivo total

\begin{tabular}{lcc|cc}
\hline \multirow{2}{*}{ Unidade } & \multicolumn{2}{c|}{ Jovens internados } & \multicolumn{2}{c}{$\begin{array}{l}\text { Jovens envolvidos em } \\
\text { ocorrências em 2014 }\end{array}$} \\
\cline { 2 - 5 } & Total & $\%$ & \multicolumn{2}{c}{ Total } \\
\hline UNIRE & 215 & $70 \%$ & 62 & $66 \%$ \\
UIBRA & 55 & $18 \%$ & 21 & $22 \%$ \\
UNISS & 38 & $12 \%$ & 11 & $12 \%$ \\
\hline Total & 308 & $100 \%$ & 94 & $100 \%$ \\
\hline
\end{tabular}

Fonte: Cadin da Uniss, Uibra e Unire. Elaborada pela autora.

Observa-se que a proporção de jovens envolvidos em ocorrências em 2014 é bastante similar a de jovens internados. Dessa forma, a Unire possui o maior número de jovens envolvidos em ocorrências disciplinares em 2014, com 66\% do efetivo total. A unidade de Brazlândia apresentou o total de 21 jovens envolvidos em ocorrências em 2014, o que representa $22 \%$ do total de jovens envolvidos em ocorrências naquele ano. No entanto, este dado deve ser analisado com cautela. A Uibra teve pouco mais de três meses de funcionamento em 2014, sendo que a maioria dos jovens que se encontravam nessa unidade no dia 2 de janeiro de 2015 praticaram estas ocorrências quando estavam internados em outras unidades.

Grande parte do efetivo de jovens da Uibra é proveniente da Unire. Em setembro de 2014, 52 jovens foram transferidos da Unire para a Uibra. A seleção destes jovens não considerou a proximidade com a moradia, mas a dificuldade de convívio na unidade, o que explica que os jovens transferidos foram aqueles que tinham muitos "problemas" na Unire. Por ter acompanhado o processo de transferência, enquanto parte da equipe técnica, observei que os jovens que estavam em situação de proteção à integridade física (PIF), isto é, que estavam isolados devido a ameaças que colocavam sua integridade física e psicológica em risco, e os jovens que apresentavam envolvimento em muitas ocorrências disciplinares foram os escolhidos para a unidade de Brazlândia.

Observa-se que na Uniss encontra-se o menor número de jovens em cumprimento de medida socioeducativa e também que apresentou envolvimento em ocorrências 
disciplinares em 2014. Dessa forma, dos 94 jovens, $12 \%$ estavam internados naquela unidade, ou seja, apenas 11 jovens da Uniss tinham cometido uma ou mais ocorrências disciplinares ao longo de 2014. Uma explicação para essa baixa incidência pode estar relacionada ao critério de bom comportamento utilizado pelo sistema judiciário para a concessão do benefício de saídas. O registro de ocorrências disciplinares na avaliação semestral do jovem, em forma de relatório, contribui para uma avaliação negativa que impede a concessão de benefícios ou implica na perda do benefício já concedido.

Dois terços (66\%) dos jovens do efetivo do dia 2 de janeiro de 2015 com infrações no ano de 2014 estavam internados na Unire. A Uibra abarcou 22\% dos 94 jovens internados que tiveram ocorrências nesse ano. O Gráfico 2 traz a representação da distribuição dos jovens com envolvimento em ocorrências disciplinares no ano de 2014 por cada unidade.

\section{Gráfico 2 - Jovens envolvidos em ocorrências disciplinares em 2014 por unidade}

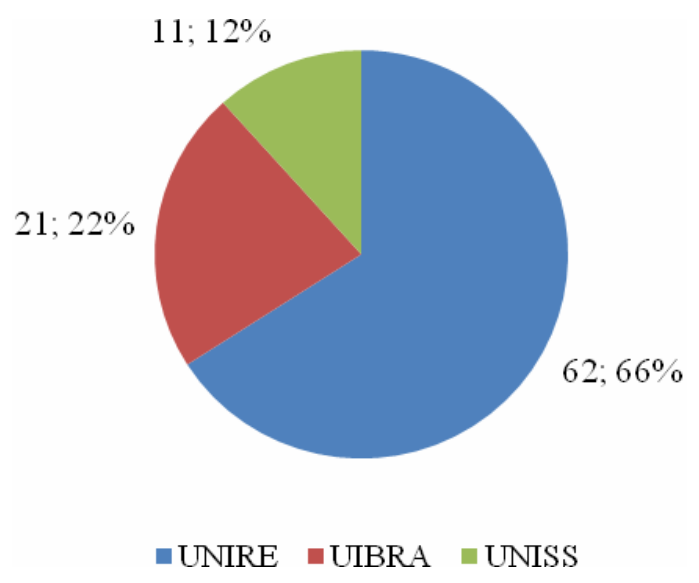

Fonte: Cadin da Uniss, Uibra e Unire. Elaborado pela autora.

\subsubsection{Unidades e ocorrências disciplinares}

No ano de 2014, ocorreram 397 ocorrências disciplinares nas unidades de internação do Distrito Federal que acautelam jovens em cumprimento de medida socioeducativa de internação. Deste total, 212 ocorreram na Unire, 165 na Uniss e 20 na Uibra, conforme mostra o Gráfico 3. A Unire apresenta 53\% do total de ocorrências e a 
Uniss, 42\%. Assim, 95\% das ocorrências registradas no ano de 2014 concentram-se nestas unidades.

\section{Gráfico 3 - Ocorrências disciplinares em 2014 por unidade}

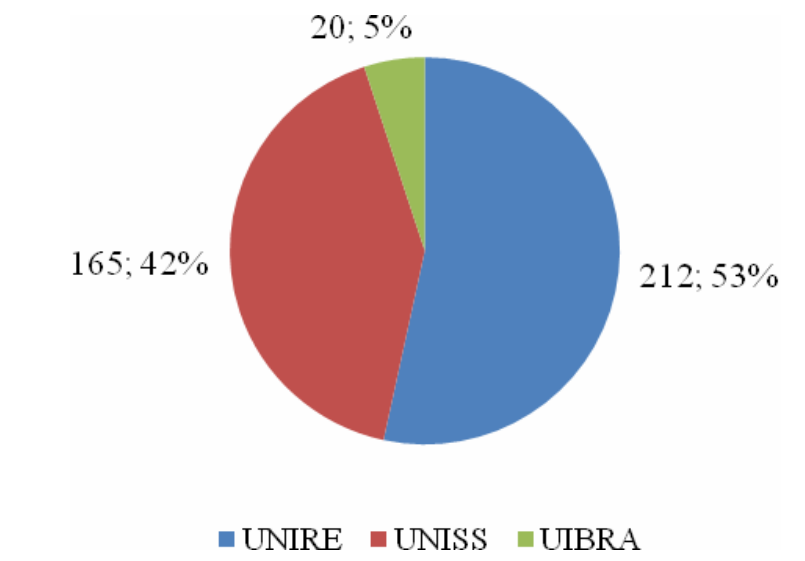

Fonte: Cadin da Uniss, Uibra e Unire. Elaborado pela autora.

Para entender melhor esse quadro geral, algumas considerações são necessárias. Como mencionado, somente a partir do fim de março a Unire passou a atender exclusivamente maiores, o que vale ressaltar que nem todas as ocorrências podem ter sido de autoria exclusiva de jovens. Já a Uibra teve apenas um pouco mais de três meses de funcionamento em 2014. Ela começou a funcionar no fim de setembro de 2014. E na Uniss, por ser uma unidade mista, que atende adolescentes e jovens, as 165 ocorrências podem ter sido cometidas por um dos dois grupos. Outra ressalva importante, no caso da Uniss, é que por ser uma unidade de saídas sistemáticas, os internos não permanecem na unidade durante a maioria dos finais de semana, e 29, ou seja, 18\% das ocorrências, são evasões - tipo de ocorrência em que não cabe nenhum procedimento, além da comunicação para o Poder Judiciário.

A evasão da medida socioeducativa de internação é o não retorno à unidade para cumprimento da medida após alguma atividade externa, seja para educação profissional ou saídas para casa autorizadas judicialmente. As evasões podem interromper a contagem do tempo de cumprimento da medida para a elaboração das avaliações semestrais previstas no Estatuto da Criança e do Adolescente (ECA). Se um adolescente ou jovem infrator com um ano e quatro meses de cumprimento de medida socioeducativa não 
retorna à unidade de internação após uma saída especial e fica por três meses fora da instituição, quando de seu retorno, ele tem um ano e quatro meses de cumprimento de medida socioeducativa, mas reinicia-se a recontagem de tempo para uma nova avaliação de sua medida. Isto é, somente após seis meses será realizada uma reavaliação de sua medida, por meio de relatório técnico, salvo nos casos de pedido do Poder Judiciário.

Aquelas evasões por um curto período de tempo, por no máximo um mês, não atrasam a avaliação semestral do interno. Tal determinação é parte de um acordo verbal realizado entre a Vara de Execução de Medidas Socioeducativas (VEMSE) e o corpo técnico das unidades socioeducativas. $\mathrm{O}$ tempo em prisão cautelar que não for convertida em pena privativa de liberdade também é descontado do tempo de cumprimento de medida socioeducativa (BRASIL, 2012). Outra informação importante é que, no caso da Uniss, quando um interno evade ou é apreendido no sistema prisional, ele não pode mais retornar para esta unidade, ao contrário das demais, além de ter o benefício de saídas sistemáticas suspenso pelo Poder Judiciário.

Por terem pouco tempo de funcionamento, não foi possível realizar uma análise de dados em painel das unidades de Saída Sistemática e de Brazlândia, de forma a acompanhar a variação do número de ocorrências disciplinares ao longo dos últimos anos. A respeito da Unire, foi possível fazer a análise de dados em painel apenas com dados de ocorrências, conforme mostra a Tabela 3, a partir de dados fornecidos pela Gerência de Segurança (GESEG) desta unidade. Os registros da população de internos nos anos anteriores são inconsistentes. Dessa forma, não foi realizada a proporção do número de ocorrências por jovens em cada ano.

Tabela 3 - Número de ocorrências disciplinares na Unire - 2010 a 2014

\begin{tabular}{cc}
\hline Ano & $\begin{array}{c}\text { No }^{o} \text { de ocorrências } \\
\text { disciplinares }\end{array}$ \\
\hline 2010 & Não existe esse controle \\
2011 & 457 \\
2012 & 389 \\
2013 & 382 \\
2014 & 178 \\
\hline \hline
\end{tabular}

Fonte: Relatórios anuais da GESEG/Unire. Elaborada pela autora. 
Os números foram fornecidos pela Gerência de Segurança com base em relatórios anuais de controle de ocorrências. Apesar de a gestão da unidade ter sido assumida pelo Governo do Distrito Federal (GDF) em julho de 2010, não existe um relatório que mostre o número de ocorrências que ocorreram naquele ano. Além disso, somente no ano de 2014 foi elaborado um quadro geral das ocorrências disciplinares, que divide as ocorrências por mês, plantão, período da semana, autoria, procedimento, grau das ocorrências, efetivo no mês, total de ocorrências por mês e porcentagem de ocorrências por efetivo. Dessa forma, foi encontrada uma diferença nos números de 2014. No relatório anual consta o total de 178 ocorrências disciplinares e no quadro geral o total de 212. De acordo com uma servidora da Gerência de Segurança, as pequenas diferenças estão em algumas ocorrências que não são contabilizadas pelo relatório anual, como evasões, e quando não há a realização de Conselho Disciplinar.

Mesmo com essa divergência nos números do ano de 2014, verifica-se que ocorreu uma queda no número de ocorrências disciplinares ao longo dos anos na Unire. Isso pode ser explicado por diversos fatores, como, por exemplo, por uma diminuição no efetivo de internos da unidade. Entretanto, o que ocorreu foi o contrário. Ao longo dos anos, a Unire teve um aumento significativo no número de internos, chegando ao quadro de superlotação. Deste modo, considera-se que a explicação da queda no número de ocorrências disciplinares está relacionada ao fato de a unidade ter sido destinada exclusivamente para o atendimento de jovens no ano de 2014. A ameaça do sistema prisional faz com que jovens evitem ao máximo o envolvimento em ocorrências disciplinares. $\mathrm{O}$ risco de ser encaminhado para delegacia para registro de boletim policial após o envolvimento em uma ocorrência disciplinar e não voltar para a unidade está presente entre os jovens em cumprimento de medida socioeducativa de internação.

\subsection{O PROCEDIMENTO SOCIOEDUCATIVO DE ENCAMINHAMENTO PARA A DELEGACIA}

O regime disciplinar é independente da responsabilidade civil ou penal que provenha de uma ocorrência disciplinar (BRASIL, 2012). Não consta em nenhum dos principais documentos que regulamentam e dão diretrizes para o funcionamento das unidades socioeducativas o procedimento de encaminhamento para delegacia para o registro de boletim policial nos casos de envolvimento em ocorrências disciplinares 
dentro das unidades de internação, contudo, a maioridade civil, no caso dos jovens internados, permite o procedimento para adultos. Existe uma frequência no procedimento de encaminhamento para delegacia que foi percebida durante o exercício profissional e que os números coletados na pesquisa comprovaram. Das 397 ocorrências disciplinares que ocorreram no ano de 2014, 129 (32\%) culminaram em encaminhamentos para delegacia para registro de boletim policial.

Considerando as 212 ocorrências disciplinares na Unire, 105 (49\%), ou seja, praticamente a metade delas, tiveram o procedimento de encaminhamento para delegacia adotado, conforme mostra a Tabela 4. Na Uibra, o total foi de seis encaminhamentos, o que representa $30 \%$ das ocorrências nesta unidade. Na Uniss, das 165 ocorrências, 18, ou seja, $11 \%$ das ocorrências disciplinares, tiveram encaminhamentos para delegacias circunscricionais.

Tabela 4 - Tipo de ocorrência disciplinar que gerou procedimento de encaminhamento para delegacias

\begin{tabular}{|c|c|c|c|c|c|c|}
\hline Tipo de Ocorrência & Uniss & $\%$ & Uibra & $\%$ & Unire & $\%$ \\
\hline Ameaça a servidor & 2 & $11 \%$ & - & - & 5 & $5 \%$ \\
\hline Agressão Física Mútua & - & - & 1 & $17 \%$ & 21 & $20 \%$ \\
\hline $\begin{array}{l}\text { Agressão Verbal, ameaça e porte de } \\
\text { objeto proibido }\end{array}$ & - & - & 1 & $17 \%$ & - & - \\
\hline Agressão Física a adolescente & - & - & - & - & 24 & $23 \%$ \\
\hline Agressão Física a servidor & - & - & - & - & 2 & $2 \%$ \\
\hline Dano ao patrimônio & - & - & - & - & 24 & $23 \%$ \\
\hline Desacato ao servidor & - & - & - & - & 3 & $3 \%$ \\
\hline Fuga (recapturado no mesmo dia) & - & - & - & - & 3 & $3 \%$ \\
\hline Ocultação de substância entorpecente & 1 & $6 \%$ & - & - & - & - \\
\hline Portar, Usar ou Fornecer aparelho celular & - & - & - & - & 3 & $3 \%$ \\
\hline Porte de Objeto Proibido (estoque) & - & - & - & - & 1 & $1 \%$ \\
\hline Porte de substância entorpecente & 9 & $50 \%$ & 4 & $67 \%$ & 13 & $12 \%$ \\
\hline Praticar brincadeira de meia hora & - & - & - & - & 1 & $1 \%$ \\
\hline Tentativa de homicídio & - & - & - & - & 2 & $2 \%$ \\
\hline Tumulto & - & - & - & - & 3 & $3 \%$ \\
\hline Uso de substância entorpecente & 2 & $11 \%$ & - & - & - & - \\
\hline
\end{tabular}




\begin{tabular}{lccccccc} 
Uso e porte de substância entorpecente & 4 & $22 \%$ & - & - & - & - \\
\hline Total & 18 & $100 \%$ & 6 & $100 \%$ & 105 & $100 \%$ \\
\hline \hline
\end{tabular}

Fonte: Cadin da Uniss, Uibra e Unire. Elaborada pela autora.

A Uniss deve sempre ser vista em suas especificidades, por ter $18 \%$ de suas ocorrências do tipo evasões, quando o interno evade não cabe nenhum procedimento, como delegacias ou Conselho Disciplinar, além da comunicação para a Vara de Execução de Medidas Socioeducativas (VEMSE). Ressalta-se ainda que o procedimento de encaminhamento para delegacia não exclui demais procedimentos, tais como o Conselho Disciplinar, encaminhamento para Instituto Médico Legal (IML) ou transferências. Todas as ocorrências disciplinares que tiveram encaminhamentos para delegacias na Uniss e na Uibra também tiveram Conselhos Disciplinares. Os Conselhos Disciplinares ocorrem após o registro de boletim policial, isto permite que, em alguns casos, o jovem seja considerado culpado na delegacia e tenha um processo criminal instaurado e, posteriormente, no Conselho Disciplinar seja considerado inocente.

A respeito do tipo de ocorrências disciplinares que culminaram no procedimento de encaminhamento para delegacia, os dados da Tabela 4 mostram que a maioria está relacionada com agressão física a outro adolescente e mútua, dano ao patrimônio e ao uso e porte de substâncias entorpecentes. Na Uniss, 16 (89\%) dos 18 encaminhamentos para delegacia foram relacionados a substâncias entorpecentes na unidade - 9 por porte, 4 por uso e porte, 2 por uso e 1 por ocultação de substância entorpecente. Na Uibra, 4 (67\%) dos 6 encaminhamentos para delegacia também foram relacionados à substância entorpecente, mais precisamente por porte desse tipo de substância. As outras ocorrências disciplinares que geraram encaminhamentos para delegacia nas unidades de Saída Sistemática e de Brazlândia foram por agressões físicas, mútuas ou verbais, além de ameaça e porte de objeto proibido.

$\mathrm{Na}$ Unire, unidade com o maior efetivo de jovens e que apresentou 105 ocorrências com procedimento de encaminhamento para delegacias, a agressão física a adolescente e o dano ao patrimônio foram as ocorrências disciplinares que mais encaminharam jovens a delegacias para registro de boletim policial - ambas totalizaram 48 (46\%) encaminhamentos, sendo que cada um desses tipos de ocorrência foi responsável por 24 (24\%) encaminhamentos, seguidas por agressão física mútua e porte 
de substância entorpecente, com 21 (20\%) e 13 (12\%) encaminhamentos, respectivamente. É importante perceber que as agressões físicas - mútua, a adolescente e a servidor - geraram 47 encaminhamentos na Unire, isto é, $45 \%$ dos encaminhamentos para delegacia foram agressões. Na agressão física a adolescente, que representa $23 \%$, um só bate; na agressão física mútua, responsável por $20 \%$, os dois batem, mas somente em $2 \%$ dos casos um servidor apanha. Ou seja, brigas entre jovens que poderiam ter medidas internas terminam em delegacias e processos criminais. As demais ocorrências disciplinares, dentre elas, a prática de brincadeira de meia hora, que também pode significar algum tipo de agressão entre jovens, constituíram $22 \%$ do total de ocorrências da Unire.

\section{O PRISIONAL}

\subsection{DO ENCAMINHAMENTO PARA A APREENSÃO}

Uma ocorrência disciplinar dentro de uma unidade de internação pode se tornar a porta de entrada de um jovem infrator para o sistema prisional. O tempo de apreensão no sistema prisional pode variar de dias até meses. Já o retorno para a unidade de internação tem se tornado uma prática regular. O alvará de soltura é emitido com a observação de escolta policial para o retorno à unidade socioeducativa. Além do fato de permanecer apreendido no sistema prisional, outra consequência é a possível instauração de um processo criminal durante o cumprimento de uma medida socioeducativa. Existe um universo de jovens infratores que, após o término da medida socioeducativa de internação, já possuem penas a serem cumpridas enquanto adultos.

Em 2014, 32 jovens em cumprimento de medida socioeducativa de internação foram desligados do sistema socioeducativo e deram entrada no sistema prisional ${ }^{14}$. Este número diz respeito somente àqueles que foram encaminhados diretamente de uma unidade socioeducativa para o sistema prisional. Este dado não contabiliza os jovens que estavam evadidos do sistema socioeducativo e podem ter cometido algum crime ou contravenção penal durante a evasão e foram para o prisional e aqueles que após liberados da medida socioeducativa seguiram para o presídio. A grande maioria desses

\footnotetext{
${ }^{14}$ No ano de 2014, ocorreram 33 desligamentos para o sistema prisional, sendo que um mesmo jovem foi desligado por duas vezes, nos meses de abril e junho daquele ano.
} 
desligamentos, 31 deles, ocorreu em uma única unidade, na Unire. Os outros dois restantes ocorreram na Uibra. A Uniss não apresentou nenhum desligamento de jovens para o sistema prisional durante o ano de 2014.

Considerando a Unire, uma vez que as duas outras unidades foram inauguradas recentemente, a Tabela 5 mostra a quantidade de desligamentos para o sistema prisional de 2010 a 2014.

Tabela 5 - Desligamentos para o sistema prisional na Unire - 2010 a 2014

\begin{tabular}{lcl}
\hline Ano & $\mathrm{N}^{\mathrm{o}}$ de desligamentos & Observações/Especificações \\
\hline $2010^{*}$ & 05 & $\begin{array}{l}04-\text { Encaminhado à } 27^{\mathrm{a}} \text { DP e não retornou } \\
01-\text { Cumprimento de mandado de prisão preventiva }\end{array}$ \\
\hline 2011 & 06 & $\begin{array}{l}05-\text { Encaminhado à } 27^{\mathrm{a}} \mathrm{DP} \text { e não retornou } \\
01-\text { Encaminhado ao CDP }\end{array}$ \\
\hline 2012 & 25 & $\begin{array}{l}18-\text { Encaminhado à } 27^{\mathrm{a}} \mathrm{DP} \text { e não retornou } \\
06-\text { Sistema Prisional } \\
\end{array}$ \\
& $01-$ Mandado de prisão preventiva \\
\hline 2013 & 16 & $\begin{array}{l}15-\text { Sistema Prisional } \\
01-\text { Encaminhado à } 27^{\mathrm{a}} \text { DP e não retornou }\end{array}$ \\
\hline 2014 & 32 & $32-$ Sistema Prisional \\
\hline \hline
\end{tabular}

Fonte: Cadin - Unire. Elaborada pela autora. Nota: *a partir do mês de julho.

Verifica-se um aumento no número de desligamentos de jovens em cumprimento de medida socioeducativa de internação devido à apreensão no sistema prisional. As taxas mais elevadas se concentram nos anos de 2012 e 2014 . Importante ressalvar novamente que o ano de 2010 é considerado somente a partir do mês de julho, quando o GDF assumiu a gestão integral da unidade. Outra ressalva é que, apesar de no ano de 2014 serem apresentados 32 desligamentos no Cadin, após a checagem nos dossiês dos jovens desligados verificou-se um erro no cadastro. Um dos jovens não teria sido desligado em março de 2014, conforme consta no cadastro, mas em março de 2015. Assim, o número de jovens desligados na Unire em 2014 em virtude da apreensão no sistema prisional no ano de 2014 foi de 31 jovens.

Dessa forma, dos 105 encaminhamentos para delegacias para registro de boletim policial realizados pela Unire em 2014, 31 jovens ficaram presos, o que representa quase $30 \%$ das ocorrências disciplinares que culminaram no procedimento de encaminhamento para delegacias nessa unidade. Destes 31 casos, 22 foram por dano ao patrimônio 
público, cinco por mandado de prisão, três por tentativa de homicídio e um por tráfico de drogas. Ao olhar para os jovens do efetivo do dia 2 de janeiro de 2015, 13 foram desligados do sistema socioeducativo e estiveram apreendidos no sistema prisional em 2014. Isto é, dos 308 jovens que se encontravam em cumprimento de medida socioeducativa de internação no Distrito Federal em 2 de janeiro de 2015, 13 (4\%) deles, ao serem encaminhados para delegacias pelo sistema socioeducativo ao longo do ano de 2014, ficaram apreendidos no sistema prisional.

\subsection{JOVENS PRESOS}

Treze dos 308 jovens, ou seja, 4\% dos jovens que se encontravam em cumprimento de medida socioeducativa de internação no Distrito Federal no dia 2 de janeiro de 2015, ficaram apreendidos no sistema prisional durante o ano de 2014. Isto é, 13 jovens foram desligados do sistema socioeducativo por certo período de tempo, ficaram apreendidos no sistema prisional e depois retornaram para o sistema socioeducativo no decorrer de um ano.

Sobre esses treze jovens, todos haviam passado por outras medidas socioeducativas antes de chegar à medida mais gravosa, a internação. Dentre esses jovens, quatro não somente haviam passado por outras medidas socioeducativas como estavam em sua segunda internação. Já internados, a metade vivenciou situação de proteção à integridade física (PIF), ou seja, além de privados de liberdade, estiveram isolados. Os módulos de convivência protetora foi o destino de cinco deles. A necessidade de proteção destes jovens, seja no isolamento ou no módulo especial, pode ter sido justificada pelos cortes. Foram encontrados registros de automutilação e tentativas de suicídio por parte de três deles. Além disso, três também representam os que estavam internados há mais de três anos, não por erro do Poder Judiciário. Ao contrário, a lei estava sendo corretamente cumprida. Assim, uma medida socioeducativa de internação era declarada extinta, mas logo em seguida outra começava.

Em relação ao ato infracional que haviam sido sentenciados para a atual medida socioeducativa de internação, cinco deles estavam internados por roubo. Os demais se distribuem em homicídio (3), tentativa de homicídio (1), tentativa de latrocínio (1), tráfico de drogas (1), furto (1) e tentativa de furto (1). O local da prática do ato 
infracional era reservado para a periferia, o mesmo local de residência. Local de residência e local do ato infracional se confundem. Ceilândia, Guará, Paranoá, Recanto das Emas, Samambaia, Santa Maria, São Sebastião e Sobradinho eram as principais regiões em que se cometia a violência e onde se morava. $\mathrm{O}$ que entrou mais novo na unidade de internação foi aos 14 anos de idade e o mais velho aos 19 anos. Quase todos, assim que completaram a maioridade, foram para o sistema prisional. Dos 13 jovens, 11 deram entrada no sistema prisional aos 18 anos e os dois outros, um aos 19 anos e o segundo aos 20 anos. Um destes onze jovens foi para o sistema prisional quatro dias após o seu aniversário de 18 anos.

A ocorrência disciplinar da qual a grande maioria foi acusado e que se configurou em crime foi a de dano ao patrimônio público, art. 163, parágrafo único, inciso III do Código Penal. Dos treze jovens, 12 foram apreendidos no sistema prisional pelo crime de dano ao patrimônio público e um por tráfico de drogas (arremesso de um pão com duas trouxas de pó branco, sem a quantidade descrita). O patrimônio público danificado foram colchões, chuveiros, vasos sanitários e pias dos alojamentos das unidades. Rasgar colchão e quebrar chuveiro, vaso sanitário e pia abriram as portas do sistema prisional para os jovens já internados. Do sistema socioeducativo para o sistema prisional, além do crime de dano ao patrimônio público, o desespero por estar internado também foi registrado. São relatados, em três registros de ocorrência disciplinar, que o motivo de terem danificado pias, vasos, chuveiros e colchões encontra-se no fato de não quererem mais permanecer onde estavam. Um destes três assegurou, em tom de desespero e raiva, que se continuasse isolado em seu alojamento danificaria outras partes das instalações. Os outros dois, no mesmo tom, disseram que preferiam "descer para a Papuda". Os três jovens se encontravam em situação de isolamento no módulo disciplinar.

Por volta das 10 h do dia 02 de janeiro do ano em curso, no módulo 07, quando o socioeducando retornava da oficina de panificação questionou o seu prazo de permanência no módulo 07, momento em que, o Chefe de Módulo informou que o adolescente estava de PIF (proteção da integridade física) no módulo e sendo assim, por prazo indeterminado. Mais tarde, o adolescente quebrou o chuveiro e a torneira do alojamento. Diante disso, foi encaminhado a $27^{\mathrm{a}} \mathrm{DP}$ para registro de ocorrência sob $\mathrm{n}^{\circ}$. 0000/2014 onde ficou apreendido naquela Delegacia (Ocorrência Disciplinar)15.

\footnotetext{
${ }^{15}$ A data da ocorrência foi alterada para o primeiro dia útil do ano de 2015 (data de referência do efetivo neste estudo). Além disso, os nomes do jovem e do chefe de módulo descritos na ocorrência e o número do registro de ocorrência policial foram subtraídos.
} 
O período mínimo de apreensão no sistema prisional foi de quatro dias e o máximo oito meses. É possível que o tempo não seja exato, considerando que o jovem pode ser liberado do prisional e não retornar no mesmo dia para o sistema socioeducativo. Há casos em que a liberação do sistema prisional significa apenas uma liberação. No entanto, como mencionado, foram encontrados nos dossiês dos jovens alvarás de soltura e termos de recebimento de preso com a seguinte observação: o réu deverá ser encaminhado à Unire para prosseguir cumprindo a medida socioeducativa. 


\section{CONSIDERAÇÕES FINAIS}

A medida socioeducativa de internação pode ser estendida até que se completem 21 anos de idade. Existe uma população de jovens entre 18 e 20 anos de idade que se encontra internada em unidades socioeducativas brasileiras. No Distrito Federal, essa população ocupa uma unidade de grande porte inteira e, em menor número, outras duas. O caráter pedagógico deve se sobrepor ao caráter sancionatório no tratamento de adolescentes e jovens infratores, a fim de que, além de responsabilizar pelo ato infracional cometido, a medida socioeducativa possa contribuir com a inclusão social e com o desenvolvimento pessoal e social do adolescente ou jovem a ela vinculado (BRASIL, 2006).

No entanto, mesmo diante destes objetivos e submetidos ao controle penal do sistema socioeducativo, a maioridade civil acarreta diferenças no acompanhamento socioeducativo, principalmente, quando um de seus membros apresenta uma prática considerada transgressora às regras da instituição. Uma falha ou um comportamento proibido pode se enquadrar em uma ocorrência disciplinar prevista em regimento interno. Para cada ocorrência disciplinar, uma série de procedimentos institucionais pode ser adotada, desde diferentes encaminhamentos até a instauração de um conselho interno composto por servidores do corpo técnico e da segurança, com objetivo de definir uma sanção. Nesses procedimentos adotados, isto é, nas práticas socioeducativas, foi observada uma lógica que visa à educação pela punição e disciplina.

Para além dos mecanismos internos de punição, o sistema prisional vem sendo acionado por meio de práticas socioeducativas. O procedimento de encaminhamento para delegacias após o envolvimento em uma ocorrência disciplinar para o registro de boletim policial é uma destas práticas. O jovem, após cometer uma ocorrência disciplinar, é encaminhado para uma delegacia para registro de boletim policial, podendo ser detido em flagrante. Punido pelo sistema prisional, retorna para o sistema socioeducativo para dar continuidade ao cumprimento da medida, com a possibilidade de ainda ter uma nova sanção. O objetivo deste estudo não foi questionar a legalidade desse procedimento, mesmo sabendo que princípios jurídicos possam estar sendo desrespeitados. O presente estudo se propôs a problematizar a perversidade desse procedimento e de demais práticas socioeducativas que, em vez de ressocializar, conforme preconizam, disciplinam, punem e normalizam. 
Ao analisar o duplo controle penal que vem sendo estabelecido sobre os jovens internados em unidades socioeducativas, verifica-se que existe uma ameaça do sistema prisional no cotidiano destes jovens. Ao passo que, do total das ocorrências disciplinares que ocorreram no ano de 2014, 32\% terminaram em delegacias para registro policial. $\mathrm{Na}$ maioria dos casos, trata-se de dano ao patrimônio, de brigas entre jovens ou da posse de algum tipo de substância entorpecente. Entretanto, como mencionado, o procedimento pode ter desdobramentos que não se resumem ao registro policial. Vinte e seis $(20 \%)$ jovens em 2014 foram desligados do sistema socioeducativo devido à apreensão no sistema prisional após o cometimento de uma ocorrência disciplinar dentro de uma unidade de internação. Na maioria das ocorrências, por terem danificado pias, chuveiros, vasos sanitários e colchões.

Um olhar mais atento sobre esta população identificou em treze jovens situações que merecem ser examinadas. Cinco desses jovens estavam internados por roubo. A atual medida de internação que estava sendo executada era a última de uma série de medidas socioeducativas anteriormente impostas, sendo que quatro jovens estavam em sua segunda internação. A metade vivenciou na internação a situação de proteção à integridade física (PIF), sendo os módulos de convivência protetora o destino de cinco deles. Em três casos foram encontrados registros de automutilação e tentativas de suicídio. Por fim, a apreensão de onze destes treze jovens ocorreu assim que os mesmos completaram a maioridade, sendo que doze foram para o sistema prisional pelo crime de dano ao patrimônio público.

Esses casos ilustram considerações importantes sobre o que vem ocorrendo no sistema socioeducativo do Distrito Federal. Dentro das unidades, encontramos adolescentes e jovens em situação de extremo sofrimento, que pode se agravar com o encaminhamento para o sistema prisional por condutas que poderiam ser responsabilizadas e trabalhadas internamente, considerando os objetivos da medida socioeducativa e a primazia de seu caráter pedagógico. A medida socioeducativa de internação é a medida mais gravosa e deve ser aplicada em último caso, avaliando-se as condições do adolescente para o seu cumprimento. Diante disso, ou os adolescentes e jovens não estão cumprindo as medidas anteriormente impostas e/ou as medidas anteriores não estão funcionando como deveriam, isto é, o que vem sendo feito nas medidas mais brandas não evitam a medida mais dura. Ou, por outro lado, existe uma 
tendência em internar, sendo que a própria medida socioeducativa de internação não consegue evitar novas internações, incluindo a prisão.

Neste sentido, questiona-se o que vem sendo realizado nas unidades socioeducativas. A disciplina perpassa de tal forma as práticas ali estabelecidas que práticas verdadeiramente socioeducativas se perdem naquele contexto. A vigilância e a observação constantes nas atividades e nos procedimentos socioeducativos, as avaliações e os diagnósticos emitidos em relatórios e as punições e os julgamentos encontrados nas sentenças, ambientes e demais práticas institucionais, como no caso dos conselhos disciplinares, não só punem e disciplinam, mas mais do que isso, normalizam estes adolescentes e jovens que encontram-se internados. As similaridades entre a prisão e as unidades socioeducativas de internação assustam. O caráter pedagógico se perde em meio às grades, às cabeças baixas, aos pareceres e às sanções. A questão referente a se é possível desenvolver instituições que eduquem e, ao menos, contribuam com o processo de autodeterminação do sujeito, se refaz neste estudo, visto que a inclusão social não passa e não passará pelo encarceramento.

O estudo sobre a duplicidade do controle penal sobre os jovens em cumprimento de medida socioeducativa de internação mostrou que os sistemas socioeducativo e prisional atuam em uma relação de continuidade. Uma relação tão íntima que o segundo não espera o primeiro terminar, atravessa-o sem pudores, dentro da legalidade, por meio de práticas institucionais. O sistema socioeducativo, por meio de suas práticas, além de não estar evitando a prisão conforme é o previsto, está internando mais ao longo do tempo. Nos últimos cinco anos, o Brasil apresentou aumento na aplicação de medida socioeducativa de internação. O que vai ao encontro do ritmo acelerado de crescimento da população carcerária do país.

Compreender esse processo de encarceramento em massa, de maneira mais ampla, para fora dos limites das grades, implica refletir a respeito do Estado e seu papel no atual estágio de desenvolvimento do sistema capitalista. Um Estado com limites sociais bem definidos, mas sem limites quando o assunto é punir. Percebe-se que um novo consenso em relação ao campo do controle do crime, de origem estadunidense, passa a se reproduzir nos discursos midiáticos e a influenciar na definição de políticas públicas em determinados países, inclusive no Brasil. Um consenso que criminaliza a pobreza e desconsidera questões sociais e econômicas na causa da criminalidade. 
Reconhecer que essas pessoas encarceradas são as mesmas que são ou que deveriam ser atendidas por políticas sociais e problematizar a atual função do encarceramento, seja para ressocializar, neutralizar, disciplinar, controlar, punir ou, simplesmente, estocar e depositar pessoas, faz-se essencial para aqueles que dedicam se ao estudo das políticas sociais. Existe uma relação entre as políticas penais e sociais que não se realiza somente pelo encarceramento em massa e seu caráter seletivo, mas pelo controle e vigilância permanentes impostos aos pobres. Pensar criticamente a respeito das consequências desse processo de criminalização e controle intenso, em particular no presente estudo, dos jovens internados em unidades socioeducativas, é fundamental para a elaboração de estratégias de superação nesse espaço permeado de contradições. 


\section{REFERÊNCIAS}

ABRAMOVAY, Pedro. Um pacto para vencer nossa maior tragédia desde a escravidão. In: 9o Anuário Brasileiro de Segurança Pública 2015. Disponível em: <http://www.forumseguranca.org.br/>. Acesso em: 22 jan. 2016.

ADORNO, Sérgio. A Gestão Urbana do medo e da insegurança - Violência, Crime e Justiça Penal na Sociedade Brasileira Contemporânea. Tese de livre-docência. São Paulo: Universidade de São Paulo, USP, Parte II - Capítulo 2, 1996.

BRASIL. Lei n. 8069, de 13 de julho de 1990. Dispõe sobre o Estatuto da Criança e do Adolescente e dá outras providências. Disponível em: <http://www.planalto.gov.br/ccivil_03/LEIS/L8069.htm>. Último acesso em: 20 fev. 2016.

Sistema Único de Segurança Pública. Departamento de Pesquisa, Análise da Informação e Formação de Pessoal em Segurança Pública. Secretaria Nacional de Segurança Pública, Ministério da Justiça, 2003.

. Resolução n. 119/2006. Dispõe sobre o Sistema Nacional de Atendimento Socioeducativo (Sinase). Secretaria Especial dos Direitos Humanos. Brasília: Conanda, 2006.

Lei n. 12.594, de 18 de janeiro de 2012. Institui o Sistema Nacional de Atendimento Socioeducativo (Sinase) e dá outras providências. Disponível em: <http://www.planalto.gov.br/ccivil_03/_ato2011-2014/2012/lei/112594.htm>. Último acesso em: 20 fev. 2016.

Presidência da República. Secretaria de Direitos Humanos (SDH). Plano Nacional de Atendimento Socioeducativo: Diretrizes e eixos operativos para o SINASE. Brasília: Secretaria de Direitos Humanos da Presidência da República, 2013a. Disponível em: <http://www.sdh.gov.br/assuntos/criancas-e-adolescentes/pdf/planonacional-de-atendimento-socioeducativo-diretrizes-e-eixos-operativos-para-o-sinase $>$ Acesso em: 21 jun. 2014. 
Lei n. 12.852, de 5 de agosto de 2013b. Institui o Estatuto da Juventude e dispõe sobre os direitos dos jovens, os princípios e diretrizes das políticas públicas de juventude e o Sistema Nacional de Juventude - SINAJUVE. Disponível em: <http://www.planalto.gov.br/ccivil_03/_Ato2011-2014/2013/Lei/L12852.htm>. Último acesso em: 20 fev. 2016.

Depen. Sistema Integrado de Informações Penitenciárias - InfoPen. Relatórios Estatísticos/Analíticos do Sistema Prisional Brasileiro. Ministério da Justiça. Junho, 2014a.

- Presidência da República. Secretaria de Direitos Humanos (SDH). Levantamento Anual dos/as Adolescentes em Cumprimento de Medida Socioeducativa. Brasília: Secretaria de Direitos Humanos da Presidência da República, 2014b.

. Conselho Nacional de Justiça. Supremo Tribunal Federal. Notícias. 2014c.

. Câmara dos Deputados. Câmara analisa criação de Sistema Único de Segurança

Pública. Rádio Câmara Notícias. 2014d. Disponível em: <http://www2.camara.leg.br/camaranoticias/radio/materias/RADIOAGENCIA/479019-

CAMARA-ANALISA-CRIACAO-DE-SISTEMA-UNICO-DE-SEGURANCA-

PUBLICA.html>. Acesso em: 24 jan. 2016.

Depen. Ministério da Justiça. Levantamento Nacional de Informações Penitenciárias INFOPEN - junho 2014. 2015a.

Presidência da República. Secretaria de Direitos Humanos (SDH). Levantamento Anual Sinase 2013 - Privação e Restrição de liberdade. Brasília: Secretaria de Direitos Humanos da Presidência da República, 2015b. Disponível em: <http://www.sdh.gov.br/noticias/pdf/levantamento-2013>. Acesso em: 22 nov. 2015.

BRISOLA, Elisa. Estado penal, criminalização da pobreza e Serviço Social. In: Revista SER Social, Brasília, v. 14, n. 30, p. 127-154, jan./jun. 2012. 
CARTA CAPITAL. Maioridade penal: os próximos passos. 2015. Disponível em: <http://www.cartacapital.com.br/blogs/parlatorio/maioridade-penal-os-proximos-passos930.html>. Acesso em: 29 jan. 2016.

COSTA, Sylvio. Segundo Ministério da Justiça, menores cometem menos de $1 \%$ dos crimes no país. Congresso em foco. 2014. Disponível em: $<$ http://congressoemfoco.uol.com.br/noticias/segundo-ministerio-da-justica-menorescometem-menos-de-1-dos-crimes-no-pais/>. Acesso em: 15 abr. 2015.

CRESWELL, John W. Projeto de pesquisa: métodos qualitativo, quantitativo e misto. Porto Alegre: ArtMed, 2010.

DIGIÁCOMO, Murillo José. O SINASE em perguntas e respostas. Ministério Público do Estado do Paraná. 2012. Disponível em: <http://www.crianca.mppr.mp.br/modules/conteudo/conteudo.php?conteudo=1198>. Acesso em: 29 out. 2014.

DINIZ, Debora. Pesquisas em cadeia. Revista Direito GV, São Paulo, 11(2), p. 573-586, jul./dez. 2015a. Disponível em: <http://dx.doi.org/10.1590/1808-2432201525>. Acesso em: 22 jan. 2016.

$2015 b$.

Cadeia: Relatos sobre mulheres. 1. ed. Rio de Janeiro: Civilização Brasileira,

DINIZ, Debora; GUERRIERO, Iara. Ética na pesquisa social: desafios ao modelo biomédico. In: DINIZ, Debora; SUGAI, Andréa; GUILHEM, Dirce; SQUINCA, Flávia (Org.). Ética em pesquisa: temas globais. Brasília: LetrasLivres e EdUnB, 2008.

DURANTE, Marcelo Ottoni. Avanços e Desafios na Implantação do Sistema Nacional de Estatísticas de Segurança Pública e Justiça Criminal (SINESPJC), 2009. In: Fórum Brasileiro de Segurança Pública. Postado em 10/03/2014. Originalmente publicado no III Anuário Brasileiro de Segurança Pública. Disponível em: <http://www.forumseguranca.org.br/>. Acesso em: 22 jan. 2016. 
FOUCAULT, Michael. Vigiar e Punir: nascimento da prisão. 42. ed. Petrópolis, RJ: Vozes, 2014.

GARLAND, D. A cultura do controle: crime e ordem social na sociedade contemporânea. Rio de Janeiro: Revan, 2008.

GHRINGHELLI, Rodrigo. Adolescentes em Conflito com a Lei - Atos infracionais e medidas socioeducativas. In: $9^{\circ}$ Anuário Brasileiro de Segurança Pública 2015. Disponível em: <http://www.forumseguranca.org.br/>. Acesso em: 22 jan. 2016.

GIBBS, Graham. Codificação e categorização temáticas. In: Análise de Dados Qualitativos. Porto Alegre: ArtMed, 2008. p. 59-78.

GOFFMAN, Erving. Manicômios, Prisões e Conventos. São Paulo: Perspectiva, 2013.

GOVERNO DO DISTRITO FEDERAL (GDF). Secretaria de Estado da Criança do Distrito Federal (Secria). Projeto Político Pedagógico das Medidas Socioeducativas no Distrito Federal. Internação. Brasília, 2013a.

. Secretaria de Estado da Criança do Distrito Federal. Subsecretaria do Sistema Socioeducativo. Regimento Interno das Unidades de Internação do Distrito Federal. Brasília, 2013b.

Secretaria de Estado da Criança do Distrito Federal. Unidades de Internação. Brasília, 2014a. Disponível em: <http://www.crianca.df.gov.br/subsis/geinpe-gerenciade-internacao-provisoria-e-estrita/316.html . Acesso em: 9 set. 2015.

Secretaria de Estado da Criança do Distrito Federal. Construindo uma nova realidade. Brasília, 2014b.

LIMA, Renato Sérgio de; BUENO, Samira. O eterno presente da segurança pública brasileira. In: $9^{\circ}$ Anuário Brasileiro de Segurança Pública 2015. Disponível em: <http://www.forumseguranca.org.br/>. Acesso em: 22 jan. 2016. 
MARIZ, Renata; SOUZA, André de. Reduzir maioridade não fere a Constituição, avaliam Ministros do Supremo. O Globo. 2015. Disponível em: <http://oglobo.globo.com/brasil/reduzir-maioridade-nao-fere-constituicao-avaliamministros-do-supremo-15789178>. Acesso em: 29 jan. 2016.

MARTINEZ, Vinício C.; SANTOS, Fátima Ferreira P. dos. Estado Penal: a miséria à venda do Estado de Direito. Perspectivas, São Paulo, v. 36, p. 209-235, jul./dez. 2009.

NASCIMENTO, André. Apresentação à edição brasileira. In: GARLAND, D. A cultura do controle: crime e ordem social na sociedade contemporânea. Rio de Janeiro: Revan, 2008.

ROGERS, Wendy; BALLANTYNE, Angela. Populações especiais: vulnerabilidade e proteção. Revista Eletrônica de Comunicação, Informação e Inovação em Saúde RECIIS, Rio de Janeiro, v. 2, Sup.1, p.Sup.31-Sup.41, dez. 2008. Disponível em: বttp://www.reciis.icict.fiocruz.br/index.php/reciis/article/view/865/1507>. Acesso em: 23 jan. 2016.

SAMPIERI, Roberto Hernández; COLLADO, Carlos Fernández; LUCIO, Pilar Baptista. Metodologia de pesquisa. 5. ed. São Paulo: McGraw-Hill, 2013.

SAPORI, Luis Flávio. Muitas dúvidas e algumas certezas. In: $9^{\circ}$ Anuário Brasileiro de Segurança Pública 2015. Disponível em: 〈http://www.forumseguranca.org.br/>. Acesso em: 22 jan. 2016.

SINHORETTO, Jacqueline. O número de presos triplicou. Quem está sorrindo? In: 9 Anuário Brasileiro de Segurança Pública 2015. Disponível em: <http://www.forumseguranca.org.br/>. Acesso em: 22 jan. 2016.

STRAUSS, A.; CORBIN, J. Pesquisa Qualitativa: Técnicas e Procedimentos para o Desenvolvimento de Teoria Fundamentada. 2. ed. Porto Alegre: ArtMed, 2008. 
WACQUANT, Loïc. Punir os pobres: a nova gestão da miséria nos Estados Unidos [a onda punitiva]. Rio de Janeiro: Revan, 2007.

As prisões da miséria. 2. ed. Rio de Janeiro: Zahar, 2011.

WAISELFISZ, Julio Jacobo. Mapa da Violência 2012: A Cor dos Homicídios no Brasil. Rio de Janeiro: CEBELA, FLACSO; Brasília: SEPPIR/PR, 2012.

Mapa da Violência 2015: Adolescentes de 16 e 17 anos do Brasil. Rio de Janeiro: CEBELA, FLACSO; Brasília: SEPPIR/PR, 2015 a.

Mapa da Violência 2015: Mortes matadas por armas de fogo. Rio de Janeiro: CEBELA, FLACSO; Brasília: SEPPIR/PR, 2015 b. 